\title{
Rove beetles of medical importance in Brazil (Coleoptera, Staphylinidae, Paederinae)
}

\author{
Juliana S. Vieira ${ }^{1}$, Cibele S. Ribeiro-Costa² \& Edilson Caron ${ }^{3}$
}

\footnotetext{
${ }^{1}$ Instituto de Ciências Exatas e Tecnologia de Itacoatiara, Universidade Federal do Amazonas, R. Nossa Senhora do Rosário, 3863, Tiradentes, 69103-128 Itacoatiara-AM, Brazil.

${ }^{2}$ Laboratório de Sistemática e Bioecologia de Coleoptera (Insecta), Departamento de Zoologia, Universidade Federal do Paraná, Centro Politécnico, Caixa Postal 19020, 81531-980 Curitiba, PR, Brazil. stra@ufpr.br

${ }^{3}$ Setor Palotina, Universidade Federal do Paraná, Rua Pioneiro, 2153, Jardim Dallas, 85950-000 Palotina-PR, Brazil. caron@ufpr.br
}

\begin{abstract}
Rove beetles of medical importance in Brazil (Coleoptera, Staphylinidae, Paederinae). The rove beetles of the genus Paederus Fabricius, 1775 are the most important group within Coleoptera causing dermatitis around the world. The medical importance of Paederus depends on its toxic hemolymph released when these beetles are crushed on human skin. The effects are mainly dermatitis linearis and some sporadic cases of conjunctivitis. In Brazil seven species of Paederus are known to cause dermatitis: P. amazonicus Sharp, 1876, P. brasiliensis Erichson, 1840, P. columbinus Laporte, 1835, P. ferus Erichson, 1840, P. mutans Sharp, 1876, P. protensus Sharp, 1876 stat. rev., and Paederus rutilicornis Erichson, 1840. Paederus mutans and P. protensus are for the first time recorded as of medical importance, whereas the record of P. rutilicornis in Brazil is doubtful. All seven species are redescribed and a dichotomous key is provided. The geographic distributions of all species are documented. The results provided here include the most recent and relevant taxonomic revision of Paederus of the Neotropical region, the first identification key for Brazilian species and the increase of recorded species of medical importance in the world.
\end{abstract}

KEYWORD. Insecta; Neotropical; New World; pederin; skin injuries.

Rove beetles of the genus Paederus Fabricius, 1775 are the most famous beetles that cause injuries of medical importance. Besides Paederus, there are other species, for example, within Meloidae and Oedemeridae, which evolved the ability of releasing toxic substances that cause only mild cases of erythema. The toxic hemolymph released when some species of Paederus are crushed on human skin causes dermatitis and conjunctivitis that may be rated as mild, moderate and severe. The substance released is a complex of three nonproteinaceous toxins named pederin, pseudopederin and pederone. An exhaustive work about medical importance of Paederus (and its natural history) can be found in Frank \& Kanamitsu (1987), and an ethnoentomological study was made by Navarrete-Heredia \& Flores (2005).

Paederus comprises 492 valid species worldwide (A.F. Newton, pers. comm.). However, only about $4 \%$ of these species have been noticed to be of medical importance and the geographical range of incidents includes most of the tropics and subtropics. Adults of Paederus are typical rove beetles, elongate, with a maximum of $25 \mathrm{~mm}$ in length and commonly exhibiting aposematic bright colors, as head and abdominal apex darker, thorax and abdominal apex orange and elytra with metallic blue or green luster. Species of the genus occur in many environments, but are usually associated with wet places, and also have been found in rural and urban areas. Eightyeight species of Paederus are known from the Neotropical region (including Chile and southern Argentina), three of which also occur in the southwestern Nearctic region (States of Ari- zona, California and Colorado in the USA) (A.F. Newton, pers. comm.). In Brazil, 23 species have been recorded.

Frank \& Kanamitsu (1987) list nine species of medical importance occurring in the Neotropical region of which five in Brazil: P. amazonicus Sharp, 1876, P. brasiliensis Erichson, 1840, P. columbinus Laporte, 1835, P. ferus Erichson, 1840 and $P$. rutilicornis Erichson, 1840. The first record of Paederus causing dermatitis in Brazil was in Bahia state and attributed to $P$. columbinus (Silva 1912). However, since 1990, in the north and northeast of Brazil, there was an increase in the number of incidents caused by species of Paederus (Diogenes 1994; Albuquerque et al. 2008 and Amado et al. 2010). In 2009, the reported incidents reached 11 of the 27 Brazilian states: Amazonas, Pará, Ceará, Paraíba, Alagoas, Bahia, Pernambuco, Goiás, Minas Gerais, São Paulo and Paraná (Torres 1922; Froes 1935; Pickel 1940a, 1940b; Fain 1966; Diogenes 1994; Albuquerque et al. 2008; Cardoso \& Haddad 2009; Amado et al. 2010, Mammino 2011; Fonseca et al. 2012).

At the moment, the identification of most species of Paederus is difficult in the entire world and the main problem is the lack of adequate identification keys and taxonomic review studies for most geographical regions (Frank \& Kanamitsu 1987). Moreover, the correct identification of the species of Paederus of medical importance is essential for future studies with health focus. Thus, the present study aimed to make a complete taxonomic revision of species of Paederus of medical importance in Brazil, including redescription of all species, identification key and distributional lists. 


\section{MATERIAL AND METHODS}

Almost 400 adult specimens of Paederus were examined. The abbreviations cited below for each institution are used in the text (the name of the curator is given in parentheses): BMNH, The Natural History Museum, London, United Kingdom (R.G. Booth); DZUP, Coleção de Entomologia Pe. J.S. Moure, Departamento de Zoologia, Universidade Federal do Paraná, Curitiba, Brazil (L.M. Almeida); FMNH, Field Museum of Natural History, Chicago, United States of America (M.K. Thayer); INPA, Coleção Sistemática de Entomologia, Instituto Nacional de Pesquisas da Amazônia, Manaus, Brazil (A. Henriques); MZSP, Museu de Zoologia da Universidade de São Paulo, São Paulo, Brazil (S.A. Casari); SESA/ PR, Secretaria de Estado da Saúde do Paraná, Curitiba, Brazil (G.B.G. Rubio); SMS/MG, Secretaria Municipal de Saúde de Betim, Betim, Brazil (R.B. Armando); UFMA, Universidade Federal do Maranhão, Chapadinha, Brazil (F.S. Silva); ZMHB, Museum für Naturkunde der Humboldt-Universität, Berlin, Germany (J. Willers).

All species of the current study are listed in Frank's index as subgenera unassigned, thus Paederus "sensu lato" (Frank 1988). Here we do not use any subgeneric concept, since the complicated status of the subgeneric classification has been noticed in some works (Frank 1988: Li \& Zhou $2007,2009)$. We agree with the recommendation of Frank (1988) that there are two major taxonomic needs, the first of them to review and redescribe the species of the Neotropical region (in addition to other regions), and the second to extend Fagel's work (Fagel 1958) for better understanding of classification of Paederus.

Type material was examined for all species names of Paederus listed as of medical importance in Brazil, except for $P$. columbinus Laporte, 1835 (not found, probably lost) and P. lugubris Motschulsky, 1858 (syntype in the Zoological Museum of Moscow University (ZMUM), junior synonym of $P$. rutilicornis Erichson, 1840 by Blackwelder (1944)). Labels from type material are organized in sequence from top to bottom, where the data from each label are enclosed within double quotes ("“), a forward slash (/) separates lines, and information enclosed by square brackets ([]) provides added details about the labels. Comments on the type material are provided in the item "Note". Information from labels of additional material is organized, when complete, as follows: country: district/province/state, number of male and female specimens, municipality in italic, locality, extra information, date, collector (abbreviation of institution). The diagnosis of the species follows the glossary of the International Code of Zoological Nomenclature, 4 th edition, which defines as "a statement in words that purports to give those characters which differentiate the taxon from other taxa with which it is likely to be confused" (ICZN 1999). Geographic distribution of each species is listed in the text by country and followed by, when possible, state and location (enclosed by parentheses). In "Medical Importance", we list cases from the literature and some extra information, but we were unable to confirm identification for all species cited.

The morphological terminology adopted is from Naomi (1987-1990), including Beutel \& Leschen (2005) for ventral sclerites of female genitalia and Gusarov (2002) for position of aedeagus. Measurements were taken using a micrometric ocular in a stereoscopic microscope Zeiss and Leica M165 V8 Discovery C. The following abbreviations were used: BL, body length (anterior margin of the head to the posterior margin of tergite 8); BW, body width (in the humeral region); HL, maximum head length; HW, maximum head width; PL, maximum pronotum length; PW, maximum pronotum width; and EL, maximum elytra length.

Most features were observed from dried pinned specimens and some specimens were macerated in boiling water for three minutes and then segments $8-10$ were separated from the abdomen, dissected and cleared in $10 \%$ cold potassium hydroxide for ten minutes, followed by a bath of acetic acid to neutralize the hydroxide and water to remove any residue. The dissections were carried out under a stereoscopic microscope Zeiss and Leica M165 V8 Discovery C. The dissected parts were put inside microvials with glycerin or on transparent plastic board covered with Canada balsam, both pinned with the specimen. Photographs were taken with Leica DFC 500 digital camera attached to a stereoscopic microscope Leica MZ16 and the images combined using AutoMontage Pro (Syncroscopy) image processing software at "Taxonline - Rede Paranaense Coleções Biológicas", Zoology Department of the Federal University of Paraná. The final images were edited in Photoshop CS5.1.

\section{TAXONOMY}

\section{Paederus Fabricius, 1775}

Paederus Fabricius, 1775: 268 (original description, no type designated, including two species); Latreille, 1810: 427 (citation of unique species, considered type species of the genus); Frank \& Kanamitsu, 1987: 155 (natural history and medical importance); Frank, 1988: 97 (list of names applied to the genus). Type Species: Staphylinus riparius Linnaeus, 1758 (subsequent designation by Latreille 1810).

Synonymic list of generic names adopted for Paederus sensu lato: Geopaederus Gistel, 1848: x (as genus), type species: Staphylinus riparius Linnaeus, 1758 (type species by objective synonym). Poederomorphus Gautier des Cottes, 1861: 75 (as genus), type species: Poederomorphus pedoncularius Gautier des Cottes, 1861 (type fixed by monotypy) [Note: Gautier des Cottes, 1862-: xxxvi, is only notices the description of the genus done before]. Paederillus Casey, 1905: 62 (as genus), type species: Paederus littorarius Gravenhorst, 1806 (subsequent designation by Blackwelder 1939). Leucopaederus Casey, 1905: 67 (as genus), type species: Paederus ustus LeConte, 1858 (type fixed by monotypy). Pseudopaederus Bernhauer, 1915: 137 (as subgenus), type species: Paederus nigerrimus Bernhauer, 1915 (type fixed by monotypy). Gnathopaederus Chapin, 1927: 75 (as genus), type 
species: Gnathopaederus szechuanus Chapin, 1927 (type fixed by original designation). Gnathopaederus Wendeler, 1927: 1 (as subgenus), type species: Paederus turrialbanus Wendeler, 1927 (type fixed by monotypy). Paederognathus Wendeler, 1928: 37 (as subgenus, new name for the subgenus Gnathopaederus Wendeler, 1927), type species: Paederus turrialbanus Wendeler, 1927 (type species by objective synonymy) [Note: Wendeler (1931) contains the same information of Wendeler (1928)]. Neopaederus Blackwelder, 1939: 97 (as subgenus), type species: Paederus morio Mannerheim, 1830 (type fixed by original designation, but on page 120). Eopaederus Scheerpeltz, 1957: 458 (as subgenus), type species: Paederus caligatus Erichson, 1840 (type fixed by original designation). Harpopaederus Scheerpeltz, 1957: 459 (as subgenus), type species: Paederus schoenherri Czwalina, 1888 (type fixed by original designation). Heteropaederus Scheerpeltz, 1957: 460 (as subgenus), type species: Paederus fuscipes Curtis, 1826 (type fixed by original designation). Dioncopaederus Scheerpeltz, 1957: 464 (as subgenus), type species: Paederus littoralis Gravenhorst, 1802 (misspelling, cited as "litoralis") (type fixed by original designation) [Note: Paederus littoralis is subjective junior synonym of Poederomorphus pedoncularius Gautier des Cottes, 1861, then Dioncopaederus is subjective junior synonym of Poederomorphus (Herman 2003)].). Oedopaederus Scheerpeltz, 1957: 466 (as subgenus), type species: Paederus chinensis Bernhauer, 1931 (type fixed by original designation). Anomalopaederus Scheerpeltz, 1966: 400 (as subgenus), type species: Paederus lacordairei Perroud, 1864 (type fixed by original designation). Oreinopaederus Scheerpeltz, 1976: 112 (as subgenus), type species: Paederus vastus Scheerpeltz, 1976 (type fixed by original designation). Nepalopaederus Scheerpeltz, 1976: 111 (as subgenus), type species: Paederus nepalensis Scheerpeltz, 1976 (type fixed by original designation).

Diagnosis. For discussion about the diagnosis of Paederus sensu lato see Frank \& Kanamitsu (1987) and Frank (1988).

Distribution. Worldwide.

\section{Key to the species of Paederus of medical importance in Brazil}

1. Head with the same color as the pronotum (Fig. 69) .... 2 1'. Head conspicuously darker than pronotum (Fig. 1).... 3

2. Gular sutures with basal sides slightly parallel (Fig. 72); mandibles with symmetrical teeth (Fig. 71) ....

P. mutans Sharp, 1876

2'. Gular sutures with basal sides strongly convergent, almost contiguous (Fig. 104); mandibles with asymmetrical teeth (Fig. 103) P. rutilicornis Erichson, 1840

3. Labrum with conspicuous pair of teeth on the middle third (Fig. 2); vertex of head with coarse punctures (Fig. 5, larger arrow; Fig. 21)

3'. Labrum without conspicuous pair of teeth on the middle third (Fig. 36), vertex of head with fine punctures (Fig. 39)
4. Antennae and tibiae unicolor, entirely brownish yellow (Fig. 1); vertex of head microsculptured (Fig. 5, smaller arrow)... P. amazonicus Sharp, 1876

4'. Antennae and tibiae bicolor, brownish yellow and dark brown (Fig. 17); vertex of head not microsculptured (Fig.

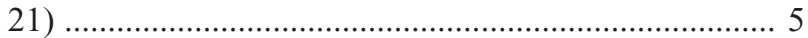

5. Elytra with apical margin oblique (Fig. 51); sexual dimorphism in mandibles: asymmetrical in male (Fig. 55) and symmetrical in female (Fig. 56)

P. ferus Erichson, 1840

5'. Elytra with apical margin truncate (Fig. 17); without sexual dimorphism in mandibles, which are symmetrical in both sexes (Fig. 19) .................. P. brasiliensis Erichson, 1840

6. Pronotum with lateral sides subparallel, in which the median third is wider than the rest (Fig. 35)

P. columbinus Laporte, 1835

6'. Pronotum with lateral sides not subparallel, in which the anterior third is wider than the rest (Fig. 85)

P. protensus Sharp, 1876

\section{Paederus amazonicus Sharp, 1876}

(Figs. 1-16)

Paederus amazonicus Sharp, 1876: 287 (original description, type locality: "Ega, Tapajos"); Frank \& Kanamitsu, 1987: 158 (main reference indicating medical importance); Frank, 1988: 100 (catalog with details about previous citations).

Diagnosis. Paederus amazonicus is similar to $P$. columbinus and $P$. protensus due to the length of the body and the apex of sternite 8 of female, which has rounded projection on the median portion of apical margin. It differs from these two species by vertex of head microsculptured and antennae and tibiae entirely brownish yellow.

Redescription. $\mathrm{BL} \approx 7.0 \mathrm{~mm}, \mathrm{BW} \approx 1.1 \mathrm{~mm}$.

Male. Body somewhat flattened dorsoventrally. Head black; subquadrate, $\mathrm{HL} \approx 1.1 \mathrm{~mm}, \mathrm{HW} \approx 0.9 \mathrm{~mm}$; vertex microsculptured (Fig. 5, smaller arrow) and with coarse punctures, distance between coarse punctures longer than the diameter of each puncture (Fig. 5, larger arrow). Eyes protruding. Antennae brownish yellow; long, almost reaching the apex of elytra. Labrum reddish brown; subtrapezoidal; apical margin teethed and with long setae; oblique lateral margins (Fig. 2). Mandibles reddish brown; falciform and symmetrical; projection bifurcated at the median of internal border, anterior tooth shorter than the posterior (Fig. 3). Gular sutures parallel on the basal two-thirds (Fig. 4, arrow). Pronotum reddish; somewhat narrowed than elytra, $\mathrm{PL} \approx$ $1.3 \mathrm{~mm}, \mathrm{PW} \approx 1.1 \mathrm{~mm}$; nearly oviform, slightly widest on the apical two-thirds; disc very convex, longitudinal median area not punctate and glabrous, lateral areas with sparse setaceous punctures. Elytra blackish blue with metallic gloss; rectangular, $\mathrm{EL} \approx 1.6 \mathrm{~mm}$; parallel sides; humeral angles slightly rounded; apical margin truncate; punctate; wings well developed. Legs long; covered with brownish yellow macrosetae; profemur entirely brownish yellow; meso- and 
metafemur with apical one-third dark brown; all tibiae entirely brownish yellow; protarsi wider than meso- and metatarsi, and the four first segments bilobed. Abdomen with segments 3-6 with parallel sides; 3-6 reddish and 7-10 black; 8th tergite subrectangular, apical margin somewhat acute medially (Fig. 6); 8th sternite subquadrate, posterior margin strongly emarginated and its internal border with parallel sides, each lateral of apical margin oblique (Fig. 7); paraproct of 9 th tergite contiguous at the basal region, apex strongly acute and long setae (Fig. 8); apex of 10th tergite rounded and with long setae (Fig. 9); 9th sternite elongate, apex slightly emarginate (Fig. 10). Aedeagus with median lobe not reaching the apex of lateral lobes (Figs. 11, 12); lateral lobes symmetrical, each apex with curved spine ventrally (Fig. 13, detail).

Female. Similar to male except for the following characters: 8th tergite subtrapezoidal and with apical margin curved (Fig. 14); 8th sternite subtriangular and rounded projection on the apical margin (Fig. 15); 9th sternite in single plate, elongate, basal margin wider than apical, apical margin truncate (Fig. 16); no genital plate.

Distribution records of material examined. Brazil: Amazonas (Careiro da Várzea, Carauari, Manacapuru, Fonte Boa, Manaus, Coari, Tonantins), Pará e Mato Grosso (Vila Bela da Santíssima Trindade). Peru.

Medical Importance. There is no record of incidents in the database of Brazilian Unified Health System (SUS, "Sistema Único de Saúde", in Portuguese). However, in the literature there are mentions about incidents with this species in the Amazon region in the early 20th century (Chapin 1926; Froes 1935).

Type material. Syntype deposited in BMNH, one male, dissected, fixed on cardboard, sealed between two plates of glass slide. Manuscript on paper card with the following information: "M"/"Paederus"/"amazonicus"/"Type"/"D.S.". The first label is printed and has the following information,"Type" [white label with red border]; the second is handwritten, "Ega" [green label]; the last two are printed and has the following information, "Brasil/Ega." [white label with midline green], "Sharp Coll/1905 - 313." [white label]. Note: Sharp (1876) comments "several individuals" observed. According to Dr. Roger G. Booth there are 9 syntypes deposited in BMNH in which we just observed one male. Presumably all syntypes are deposited in BMNH.

Additional material. PERU: $2 \mathrm{M}$, Rio Madeira, no date, no collector (FNHM). BRAZIL: Amazonas: 9 M, 4 F, Careiro da Várzea, Lago Janauacá, 10.ix.1978, R. Best col. (INPA); 26.iii.1988, Masintilli col. (INPA); 6 M, 3 F, Carauari, vii.2005, A. Henrique \& Xavier-Filho col. (INPA); 2 M, 4 F, Manacapuru, Costa do Pesqueiro 17-24.vi.2004, F. F. Xavier F. \& L. Alquino col. (INPA); 1 M, 1 F, Fonte Boa, Estrada Marmopina 23.ix.2005, J.A. Rafael \& F.F. Xavier F. col. (INPA); 4 M, 2 F, Rio Amazonas 19.x.1964, Cerq. col., (INPA); 1 M, Manaus, Comunidade Puraquequara, Fazenda N. Vitória, 18.iv.2008, G.L.S. Monte col. (INPA); 1 F, Puraquequara, Sítio Santa Vitória, 18.iv.2008, L.L. Coelho col. (INPA); 1 M, ZF2 Torre, 13-16.viii.2004, F.F. Xavier F. \& A. R. Ururahy \& A. Silva \& S. Trovisco col. (INPA); 1 M, Vila Buriti, Distrito Industrial, 28.iv.2008, E. P. Silva col. (INPA); 1 M, Anori, Comunidade Santo Antonio, 3.iii.2004, F.F. Xavier Filho col. (INPA); 1 F,
Coari, Nova Esperança, Poraquê, 7.iii.2004, F.F. Xavier F. col. (INPA); 1 M, Tonantins,16-20.ix.2005, J.A. Rafael \& F.F. Xavier F. col. (INPA); Pará: $1 \mathrm{M}$, no date, no collector (FNHM); Mato Grosso: $1 \mathrm{~F}$, Vila Bela da Santíssima Trindade, 1.x.1984, Elias Binda col. (INPA).

\section{Paederus brasiliensis Erichson, 1840}

(Figs. 17-34)

Paederus brasiliensis Erichson, 1840: 658 (original description, type locality: "Brasilia"); Frank \& Kanamitsu, 1987: 158 (main reference indicating medical importance); Frank, 1988: 103 (catalog with details about previous citations).

Diagnosis. Paederus brasiliensis is similar to P. ferus for its robust body, coarse punctuation on vertex, tridentate projection of sternite 8 and moderately to strongly bilobed apex of tergite 9 , both on female. It differs from this species by parallel lateral lobes of the aedeagus and apex somewhat rounded of tergite 8 of female.

Redescription. $\mathrm{BL} \approx 9.5 \mathrm{~mm} ; \mathrm{BW} \approx 1.6 \mathrm{~mm}$.

Male. Body somewhat flattened dorsoventrally. Head black; quadrate $\mathrm{HL} \approx 1.4 \mathrm{~mm} ; \mathrm{HW} \approx 1.4 \mathrm{~mm}$, vertex with coarse punctures, distance between the punctures longer than the diameter of each puncture (Fig. 21). Eyes protruding. Antennae brownish yellow with the three first antennomeres lightest; long, almost reaching the apex of elytra. Labrum reddish brown; subtrapezoidal, apical margin teethed and with long setae; lateral margins rounded (Fig. 18). Mandibles reddish brown; falciform and symmetrical; projection bifurcated at the median of internal border, anterior tooth shorter than the posterior (Fig. 19). Gular sutures approximate on the basal one-third basal (Fig. 20, arrow). Pronotum reddish, narrowed than elytra, $\mathrm{PL} \approx 1.7 \mathrm{~mm}, \mathrm{PW} \approx 1.4 \mathrm{~mm}$, somewhat parallel sides, slightly widest on the apical two-thirds; disc very convex, longitudinal median area not punctate and glabrous, lateral areas with sparse setaceous punctures. Elytra blackish blue with metallic gloss, rectangular, EL $\approx 2.0 \mathrm{~mm}$; parallel sides, humeral angles slightly rounded, apical margin truncate; punctate and more conspicuous than from head and pronotum; wings well developed. Legs long, covered with brownish yellow macrosetae; profemur brownish yellow on basal and dark brow on apical half; meso- and metafemur brownish yellow on basal one-third and dark brown on apical two-thirds; all tibiae entirely dark brown; protarsi wider than meso- and metatarsi, and the four first segments bilobed. Abdomen with segments 3-6 with parallel sides; 3-6 reddish and 7-10 black; 8th tergite subrectangular, apical margin somewhat rounded (Fig. 22); 8th sternite quadrate, posterior margin strongly emarginated and its internal border with parallel sides, each lateral of apical margin oblique (Fig. 23); paraproct of 9th tergite contiguous at the basal region, apex strongly acute and long setae (Fig. 24); apex of 10 th tergite rounded and with long setae (Fig. 25); 9th sternite elongate, apex truncate (Fig. 26). Aedeagus with median lobe not reaching the apex of lateral lobes; lateral lobes symmetrical, each with bristles on apical one-fifth and slightly curved spine ventrally (Fig. 29, detail). 

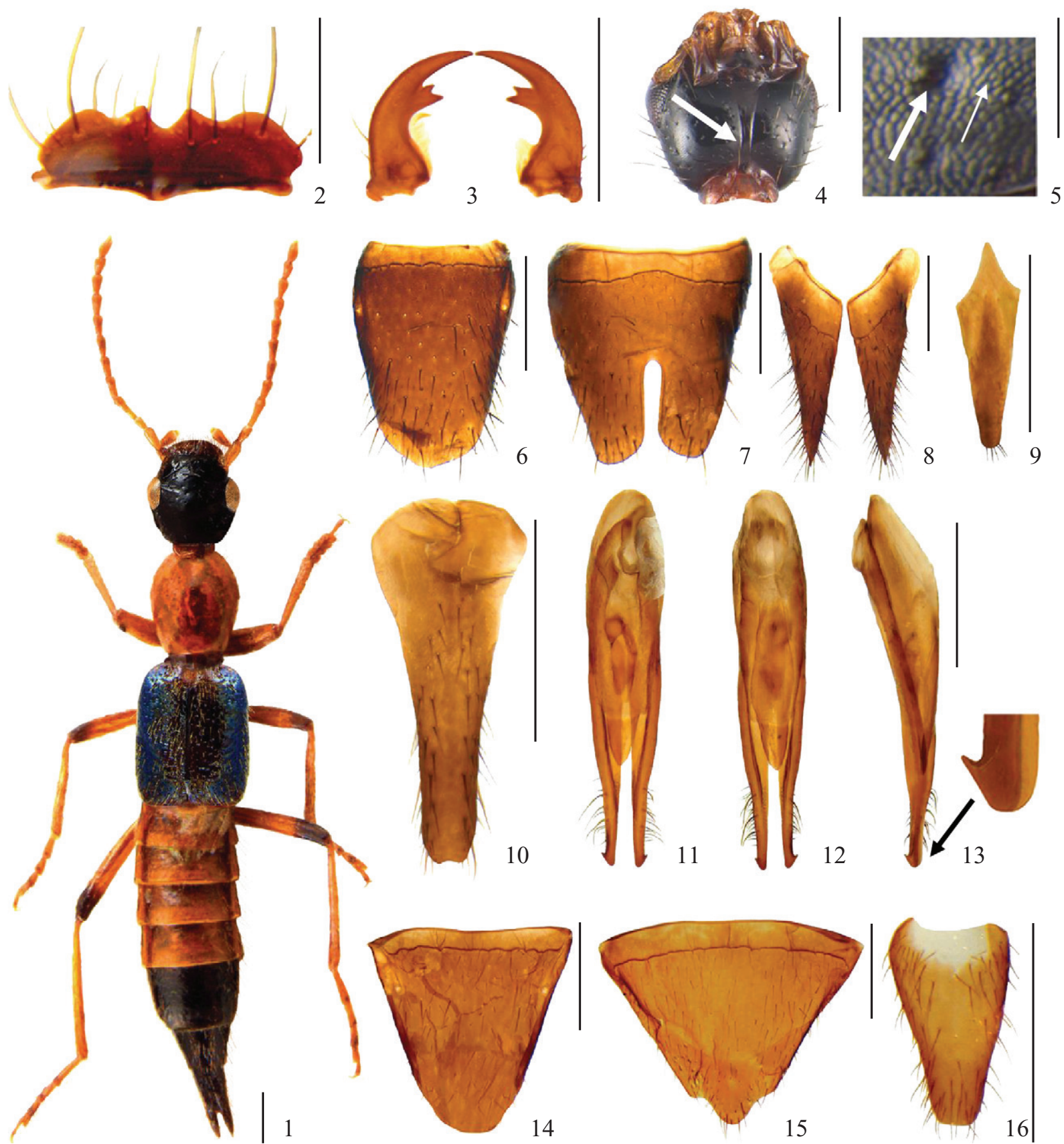

Figs. 1-16. Paederus amazonicus. Figs. 1-13, male; Figs. 14-16, female; 1. Habitus, dorsal view; 2. Labrum, dorsal view; 3 . Mandibles, dorsal view; 4. Head, ventral view; 5. Vertex of head, dorsal, punctures (larger arrow), microsculpture (smaller arrow); 6. Tergite 8, dorsal view; 7. Sternite 8, ventral view; 8. Paraprocts of the $9^{\text {th }}$ tergite, dorsal view; 9 . Tergite 10 , dorsal view; 10. Sternite 9, ventral view; 11. Aedeagus, ventral view; 12 . Aedeagus, dorsal view; 13. Aedeagus, lateral view; 14. Tergite 8, dorsal view; 15. Sternite 8, ventral view; 16. Sternite 9, ventral view. Scale bar $=1$ mm, Fig. $1 ; 0.5$ mm, Figs. $2-16$.

Female. Similar to male except for the following characters: 8th tergite subtrapezoidal and curved apical margin (Fig. $30)$; 8 th sternite subtriangular and tridentate projection on the apical margin (Fig. 31); 9th sternite in single plate, elongate, basal margin wider than apical, apical margin emarginated (Fig. 32); ventral genital plate subrectangular with apical margin strongly emarginate (Fig. 33) and dorsal plate tiny and oval (Fig. 34).
Distribution records of material examined. Brazil: Amazonas (Careiro da Várzea), Bahia (Encruzilhada), Maranhão (Chapadinha), Minas Gerais (Virginia, Águas Vermelhas, Berizal), São Paulo (Ipiranga), Paraná (Jundiaí do Sul, Ivatuba). Argentina: Jujuy (Peia).

Medical Importance. There is one record of an incident in the database of Brazilian SUS, the municipality of Ivatuba, Paraná State. However, in the literature there are mentions 

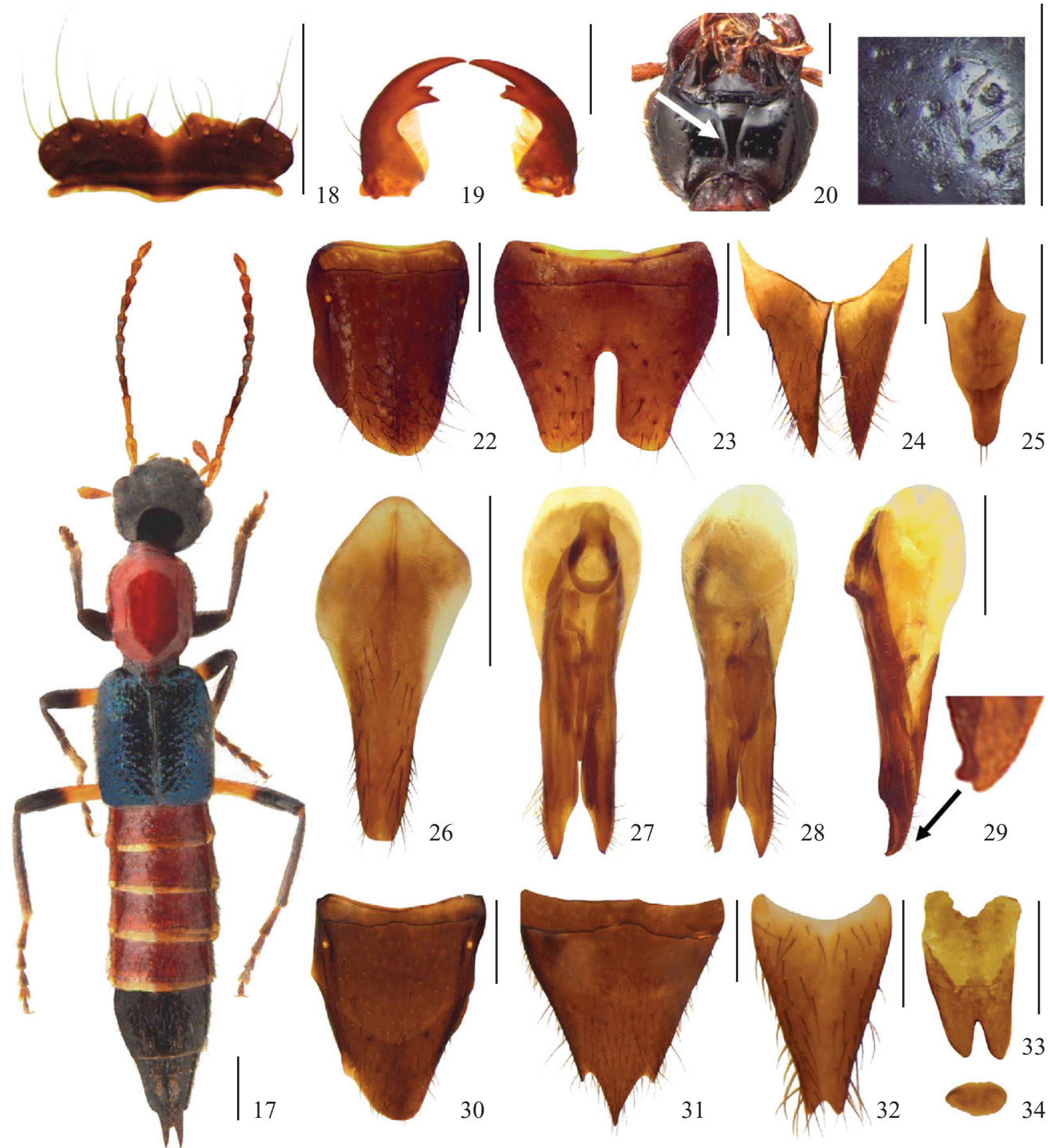

25
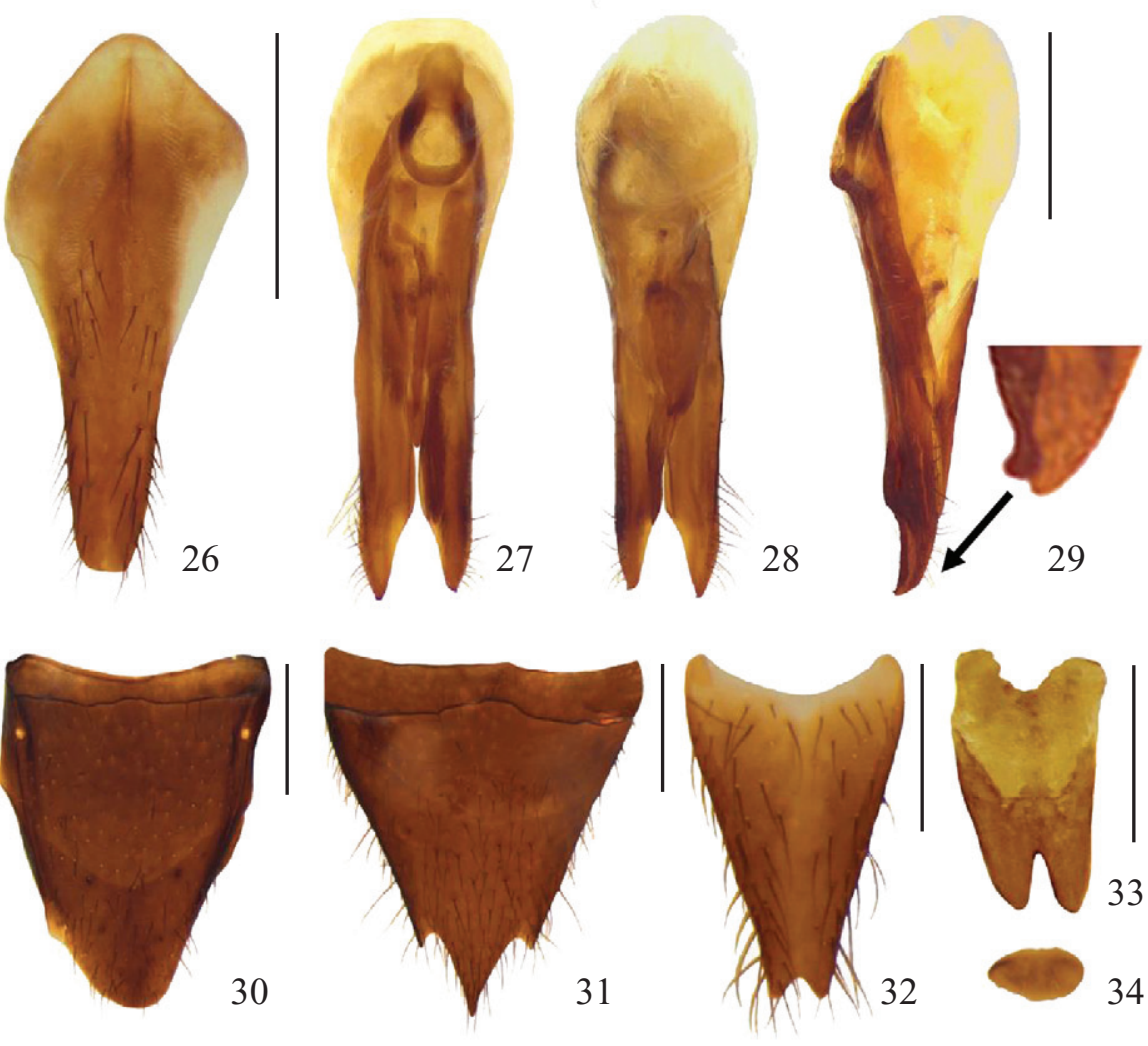

Figs. 17-34. Paederus brasiliensis Figs. 17-29, male; Figs. 30-34 female; 17. Habitus, dorsal view; 18. Labrum, dorsal view; 19. Mandibles, dorsal view; 20. Head, ventral view; 21 . Vertex of head, dorsal view; 22. Tergite 8, dorsal view; 23. Sternite 8, ventral view; 24. Paraprocts of the 9th tergite, dorsal view; 25 . Tergite 10, dorsal view; 26. Sternite 9, ventral view; 27. Aedeagus, ventral view; 28 . Aedeagus, dorsal view; 29. Aedeagus, lateral view; 30. Tergite 8, dorsal view; 31 . Sternite 8 , ventral view; 32 . Sternite 9 , ventral view; 33 . Genital plate, part; 34 . Genital plate, part. Scale bar $=1 \mathrm{~mm}$, Fig. 17; 0.5 mm, Figs. 18-34.

about incidents with this species in the following states: Bahia, Ceará, Paraíba, Pernambuco and São Paulo (Froes 1935; Pickel 1940a, 1940b; Diogenes 1994 and Albuquerque et al. 2008). Amado et al. (2010) report P. brasiliensis causing dermatitis in Betim, Minas Gerais State, but the material studied by the authors is the true P. protensus.
Type material. Syntypes, three females, one dissected, all deposited in ZMHB. One of them with five labels; the first handwritten with the following information: "Brasil. Jaleo (illegible last letter)" [green label], the second printed " 6455 " [white label], the third "brasiliensis/Er." [green label], the fourth handwritten "Type" [orange label] and the last one 
printed with the following information "SYNTYPUS/ Paederus/brasiliensis Erichson, 1840/labelled by MNHUB 2012" [red label]. Of the other two specimens, one dissected, only the first label is handwritten, "Brasilia" [white label], "Hist.-Coll. (Coleoptera)/Nr. 6455/Paederus/brasiliensis Erichs./Brasil., Sello/Zool. Mus. Berlin" [green label] "SYNTYPUS/Paederus/brasiliensis Erichson, 1840/labelled by MNHUB 2012" [red label]. Note: Erichson (1840) did not specify how many specimens he observed. We received from ZMHB three females labeled as type. Presumably all syntypes are deposited in ZMHB.

Additional material. BRAZIL: Amazonas: $1 \mathrm{M}$, Careiro da Várzea, Lago Janauacá, 27-28.III.1988, Machado L.C. col. (INPA); Bahia: 2 F, 5 M, Encruzilhada, 10-12.XII.2007, P. Grossi, Rafael \& Parizotto col. (DZUP); Maranhão: 1 F, 7 M, Chapadinha, 2009, 13.VIII.2009, 19.VIII.2009, 25.I.2010, F.S. Silva col. (DZUP); Minas Gerais: M, Virginia, Fazenda dos Campos, 13-15.II.2010, Mielke \& Casagrande col. (DZUP); 1 F, Águas Vermelhas, 13.XII.2007, P. Grossi, Rafael \& Parizotto col. (DZUP); 1 F, Berizal, Fazenda Veredão, 14.XII.2007, P. Grossi, Rafael \& Parizotto col. (DZUP); São Paulo: 1 F, 1 M, no locality, no date, Mraz LGT col. (FMNH); Paraná: 1 F, Jundiaí do Sul, Fazenda Monte Verde, 30.XI.1986, Profaupar col. (DZUP); 1 M, Ivatuba, I.2010, SESA/PR col. (DZUP); ARGENTINA: Jujuy: 1 F, Peia, Dique La Ciénaga, III.1953, A. Martines col. (DZUP).

\section{Paederus columbinus Laporte, 1835}

(Figs. 35-50)

Paederus columbinus Laporte, 1835: 123 (original description, type locality: "Colombie"); Frank \& Kanamitsu, 1987: 158 (main reference indicating medical importance); Frank, 1988: 106 (catalog with details about previous citations)

Paederus aequinoctialis Erichson, 1840: 657 (original description, type locality: "Columbia, Cayenna", described as variety of $P$. columbinus); Gemminger \& Harold, 1868: 626 (first time cited as junior synonym of $P$. columbinus Laporte, 1835); Frank \& Kanamitsu, 1987: 158 (mention as of medical importance); Frank, 1988: 99 (catalog with details about previous citations).

Diagnosis. Paederus columbinus is similar to P. amazonicus and $P$. protensus due to their similar body length and apex of sternite 8 of female, which has a projection on the median portion of apical margin. It differs from these two species by brownish color of the head and median lobe of the aedeagus with two small teeth dorsally.

Redescription. $\mathrm{BL} \approx 8.7 \mathrm{~mm}, \mathrm{BW} \approx 1.5 \mathrm{~mm}$.

Male. Body, somewhat flattened dorsoventrally. Head black, subhexagonal $\mathrm{HL} \approx 1.4 \mathrm{~mm} ; \mathrm{HW} \approx 1.3 \mathrm{~mm}$, vertex punctate, distance between the punctures longer than the diameter of each puncture (Fig. 39). Eyes protruding. Antennae brownish yellow with the antennomere 4-8 darker; long, almost reaching the apex of elytra. Labrum reddish brown, subtrapezoidal, apical margin somewhat truncate with median emargination evident and long setae, lateral margins oblique (Fig. 36). Mandibles reddish brown, falciform and symmetrical; projection bifurcated at the median of internal border, anterior tooth shorter than the posterior (Fig. 37) Gular sutures gradually converging to basal region (Fig. 38, arrow). Pronotum reddish; slightly narrowed than elytra, $\mathrm{PL} \approx 1.6$ $\mathrm{mm}, \mathrm{PW} \approx 1.4 \mathrm{~mm}$, somewhat oviform, slightly widest on the apical two-thirds; disc very convex, longitudinal median area not punctate and glabrous, lateral areas with sparse setaceous punctures. Elytra blackish blue with metallic gloss; rectangular, $\mathrm{EL} \approx 2.3 \mathrm{~mm}$, parallel sides; humeral angles slightly rounded; apical margin truncate; punctate and more conspicuous than head and pronotum; wings well developed. Legs long, covered with brownish yellow macrosetae; profemur brownish yellow and darker on apical one-fourth; meso- and metafemur brownish yellow and darker on apical two-thirds; protarsi wider than meso- and metatarsi, and the four first segments bilobed. Abdomen with segments 3-6 with parallel sides; 3-6 reddish and 7-10 black; 8th tergite subrectangular, apical margin somewhat rounded (Fig. 40); 8th sternite subquadrate, posterior margin strongly emarginated and its internal border with parallel sides, each lateral of apical margin oblique (Fig. 41); paraproct of 9th tergite contiguous at the basal region, apex strongly acute and long setae (Fig. 42); apex of 10th tergite rounded and with long setae (Fig. 43); 9th sternite elongate, apex truncate (Fig. 44). Aedeagus with median lobe almost reaching the apex of lateral lobes, the apical $1 / 3$ strongly narrowed, slightly curved dorsally and with two small teeth at the apex (Fig. 47, arrow); lateral lobes with apices contiguous, symmetrical, slightly curved ventrally and with lateral bristles on apical 1/ 2 (Figs. 45-47).

Female. Similar to male except for the following characters: 8th tergite subquadrate, apical margin slightly rounded to truncate (Fig. 48); 8th sternite subtriangular and with evident small median projection on the apical margin (Fig. 49); 9th sternite in single plate, elongate, basal margin wider than apical, apical margin rounded (Fig. 50); no genital plate.

Distribution records of material examined. Brazil: Amazonas; Ceará (Limoeiro do Norte); Maranhão (Chapadinha and Santa Helena) and Rio Grande do Norte. Panamá (Bugaba). Venezuela (Pangals).

Medical importance. There is no record of incidents in the database of Brazilian SUS. However, in the literature there are mentions of incidents with this species in Bahia and Ceará States (Chapin 1926; Froes 1935; Diogenes 1994). Here, we report the first record of accident with $P$. columbinus in Maranhão State (material collected by $\mathrm{Mr}$. Francinaldo S. Silva, Federal University of Maranhão UFMA).

Type material. Paederus columbinus: Type material not found, probably lost. Paederus aequinoctialis: Syntypes deposited in ZMHB, three males and two females (one male and one female dissected), four of them with only the first label handwritten "Columbia" [white label], the other printed "Paratypus" [dark red label]/"Hist.-Coll. (Coleoptera)/Nr. 6454/Paederus/aequinoctialis Erichs./Columb., Moritz./Zool. Mus. Berlin" [green label], "SYNTYPUS/ Paederus/aequinoctialis Erichson, 1840/labeled by MNHUB 2012" [red label]; one male, with the first label handwritten "Columb. Dai" [green label], and the other printed "6454" 

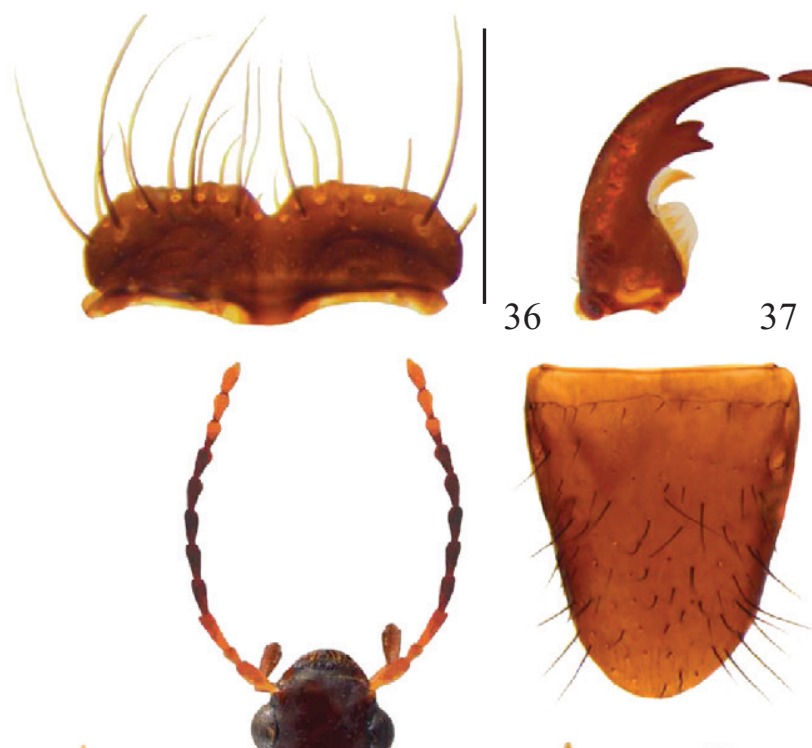

37

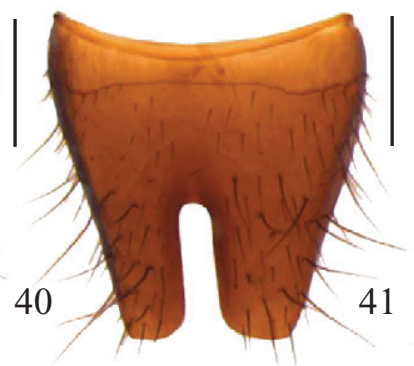

38
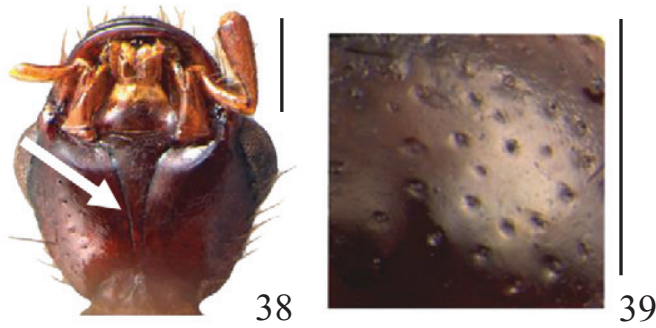
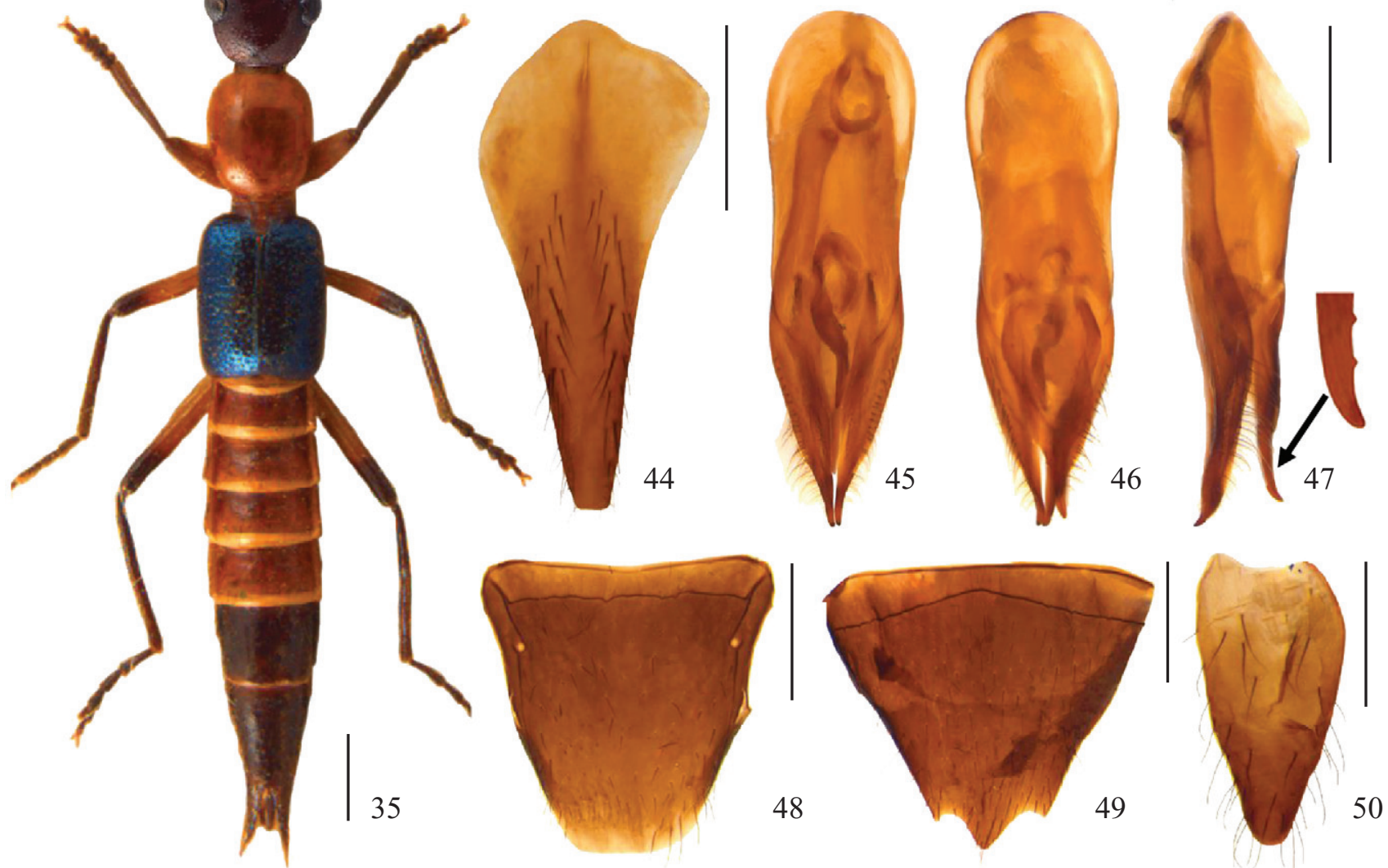

Figs. 35-50. Paederus columbinus Figs. 35-47, male; Figs. 48-50 female; 35. Habitus,dorsal view; 36. Labrum, dorsal view; 37. Mandibles, dorsal view; 38. Head, ventral view; 39. Vertex of head, dorsal view; 40. Tergite 8th, dorsal view; 41. Sternite 8th, ventral view; 42. Paraprocts of the 9th tergite, dorsal view; 43 Tergite 10, dorsal view; 44. Sternite 9, ventral view; 45. Aedeagus, ventral view; 46. Aedeagus, dorsal view; 47. Aedeagus, lateral view; 48. Tergite 8 , dorsal view; 49. Sternite 8, ventral view; 50. Sternite 9, ventral view. Scale bar $=1 \mathrm{~mm}$, Fig. $35 ; 0.5$ mm, Figs. $36-50$.

[white label], "aequinoctia/lis Er. Dai" [green label], "Holotypus" [dark red label], "SYNTYPUS/Paederus/ aequinoctialis Erichson, 1840/labeled by MNHUB" [red label]. Note: Erichson (1840) did not specify how many specimens he observed. We received from ZMHB three males and two females labeled as type. Presumably all syntypes are deposited in ZMHB. Since the type material of Laporte is lost, we consider the types from Erichson for interpreting this species.

Additional material. PANAMÁ: 2 M, Bugaba, 1905, Champion col. (FMNH). VENEZUELA: 2 F, Pangals, no date, Schuster col. (FMHN). BRAZIL: $1 \mathrm{M}$, no locality, no date, Friederichs col. (FMNH); $1 \mathrm{M}$, no locality, 1910, O A. Corwol col. (FMNH); Amazonas: 1 M, AM 010, Km 268, 19.I.1978, no collector (INPA); Ceará: 2 F, Limoeiro do Norte, 
28.III.1985, Cristoploli, V. col. (DZUP); Maranhão: 3 F, 2 M, Chapadinha, 13.VIII.2009, 21.VIII.2009, F. S. Silva col. (DZUP); Santa Helena, 18.VIII.1965, Dr. Cerq. Dd. col. (INPA); Rio Grande do Norte: 1 F, no locality, VII.1949, M. Alvarenga col. (DZUP).

\section{Paederus ferus Erichson, 1840}

(Figs. 51-68)

Paederus ferus Erichson 1840: 659 (original description, type locality: "Brasilia"); Frank \& Kanamitsu, 1987: 158 (main reference indicating medical importance); Frank, 1988: 110 (catalog with details about previous citations).

Diagnosis. Paederus ferus is similar to P. brasiliensis due to robust body, coarse punctation on vertex, tridentate projection of sternite 8 and moderately to strongly bilobed apex of tergite 9 , both on female. It differs by sexual dimorphism in the mandibles, which are asymmetrical in male, median and lateral lobes of the aedeagus strongly twisted and asymmetrical, and only a single genital plate in female.

Redescription. $\mathrm{BL} \approx 11.0 \mathrm{~mm} ; \mathrm{BW} \approx 1.9 \mathrm{~mm}$.

Male. Body somewhat flattened dorsoventrally. Head black; subquadrate $\mathrm{HL} \approx 1.8 \mathrm{~mm}, \mathrm{HW} \approx 1.8 \mathrm{~mm}$, vertex with coarse punctuation, distance between the punctures longer than the diameter of each puncture (Fig. 54). Eyes protruding. Antennae brownish yellow, the antennomere 4-8 darker; long, almost reaching the apex of elytra. Labrum reddish brown; subtrapezoidal, apical margin teethed and long setae; oblique lateral margins (Fig. 52). Mandibles reddish brown, falciform and asymmetrical, right mandible with a dorsal projection tridentate at the median and no tooth at internal border (Fig. 55, lower arrow), left mandible with a projection truncate at the apex and another bifurcate at the median of internal border (Fig.55, large arrow). Gular sutures almost contiguous at basal half(Fig. 53, arrow). Pronotum brownish, somewhat narrowed than elytra, $\mathrm{PL} \approx 1.9 \mathrm{~mm}, \mathrm{PW} \approx 1.8 \mathrm{~mm}$, widest on the apical two-thirds; disc very convex, longitudinal median area not punctate and glabrous, lateral areas with sparse setaceous punctures. Elytra blackish blue with metallic gloss, rectangular, EL $\approx 2.5 \mathrm{~mm}$; parallel sides, humeral angles slightly rounded, apical margin truncate; punctate and more conspicuous than from head and pronotum; wings well developed. Legs long, covered with brownish yellow macrosetae; profemur brownish yellow, apical half darker; meso- and metafemur dark brownish, apical one-third darker; all tibiae entirely dark brown; protarsi wider than meso- and metatarsi, and the four first segments bilobed. Abdomen with segments 3-6 with parallel sides; 3-6 reddish and 7-10 black; 8th tergite subtriangular, apical margin somewhat truncate to rounded (Fig. 57); 8th sternite subtrapezoidal, posterior margin strongly emarginated and its internal border with parallel sides, each lateral of apical margin oblique (Fig. 58); paraproct of 9th tergite contiguous at the basal region, apex strongly acute and with long setae (Fig. 59); apex of 10th tergite rounded and with long setae (Fig. 60); 9th sternite elongate, apex rounded (Fig. 61). Aedeagus with median lobe almost reaching the apex of left lateral lobe, but exceeds the right lobe (Fig. 62-63); lateral lobes strongly asymmetrical, both with apex curved ventrally (Fig. 64, arrow).

Female. Similar to male except for the following characters: symmetrical mandibles, each with bifurcate projection at the median on internal border (Fig. 56); 8th tergite subquadrate with a rounded projection on the apical margin (Fig. 65); 8th sternite subtriangular and tridentate projection on the apical margin (Fig. 66); 9th sternite in single plate, elongate, basal margin wider than apical, apical margin bilobed (Fig. 67); genital plate single, subrectangular, with apical margin sinuous (Fig. 68).

Distribution records of the material examined. Brazil: Espírito Santo (Santa Tereza); Minas Gerais (Santa Barbara, Pouso Alegre); Rio de Janeiro (Bom Jesus de Itepabo, Nova Friburgo); São Paulo (São Carlos do Pinhal, Barueri, Salesópolis, Três Irmãos); Paraná (Guaraqueçaba, Antonina, São José dos Pinhais, Morretes, Pitanga); Santa Catarina (Seara). Ecuador (Santa Inés); Bolívia (La Paz).

Medical Impotance. There is no record of incidents in the database of Brazilian SUS. However, Pickel (1940b) reported accidents in Pernambuco State, and recently, Albuquerque et al. (2008) reported incidents in Paraíba State.

Type material. Syntypes deposited in ZMHB, one male and one female, male dissected with the first three labels, except the number, handwritten and the last two printed, with the following information: "Brasil. Virm" [green label], “Type”, [red label], "ferus/Er.”, [green label], “6459”, [white label], "SYNTYPUS/Paederus/ferus Erichson, 1840/labeled by MNHUB 2012" [red label]. Female, only the first label handwritten and the last two printed: "Brasilia" [white label], "Hist.-Coll. (Coleoptera)/Nr. 6459/Paederus/ferus Erichs./Brasil., Virmnd./Zool. Mus. Berlin" [green label], "SYNTYPUS/Paederus/ferus Erichson, 1840/labeled by MNHUB 2012" [red label]. Note: Erichson (1840) did not specify how many specimens he observed. We received from ZMHB one male and one female labeled as type. Presumably all syntypes are deposited in ZMHB.

Additional material. ECUADOR: 1 M, Santa Jnéz, no date, R. Haensch S. col. (FMNH). BRASIL:, 1 F, 2 M, no locality, no date, no collector (DZUP); Espírito Santo: 2 F, Santa Tereza, 5.II.1964, C. Elias col.; 12.V.1967, C. T. \& C. Elias col. (DZUP); Minas Gerais: 1 F, Santa Barbara, Serra do Caraça, 23-25.XI.1960, Araújo \& Martins col. (MZSP); 1 M, Pouso Alegre, XII.1965, F. S. Pereira col., (MZSP); Rio de Janeiro: 1 F, Bom Jesus do Itabapoana, 1906, Walter, Ana col. (FMNH); 1 M, Nova Friburgo, 14-19. XI. 2007, P. C. Grossi col. (DZUP); São Paulo: 1 F, no locality, no date, Barbiellini col. (FMNH); 1 M, São Carlos do Pinhal, 1-8.I.1901, Riedel col. (FMNH); 1 F, Barueri, X. 1965, K. Lenko col., (MZSP); 1 F, 1 M, Salesópolis, Est. Biol. Boraceia, 1.II.1961, K. Lenko col.; 23.III.1961, Reichardt col. (MZSP); 1 F, Três Irmãos, IX.1990, Rogério Bert col. (MZSP); Paraná: 2 F, Guaraqueçaba, SPVS, 16.II.2008, E. Caron col., (DZUP); 1 F, Antonina, Reserva Sapitanduva, 31.V.1986, no collector (DZUP); 1 F, São José dos Pinhais, 8.I.1970, Giacomel - Laroca \& Becker col. (DZUP); 1 M, Morretes, IAPAR, 21.I.1985, C. I. I. F. col. (DZUP); 1 F, Pitanga, 14.VIII.1966, Moure, Marinoni col. (DZUP); Santa Catarina: 3 F, 5 M, Nova Teutônia, no date, Fritz Plaumann col. (FMNH); 1 F, 1 M, Nova Teutônia, VIII.1939, B. Pohl col. (MZSP); 1 F, 3 M, Nova Teutônia, IV.1966, F. Plaumann col. (MZSP); 15.VII.1948, no collector, V.1980, no collector (DZUP); BOLIVIA: 2 M, La Paz, Reys, Rio Beni, 1891, Balzon col., (FMNH); 1 M, La Paz, Yungas Coroico, XII.1948, A. Martines col. (MZSP). 


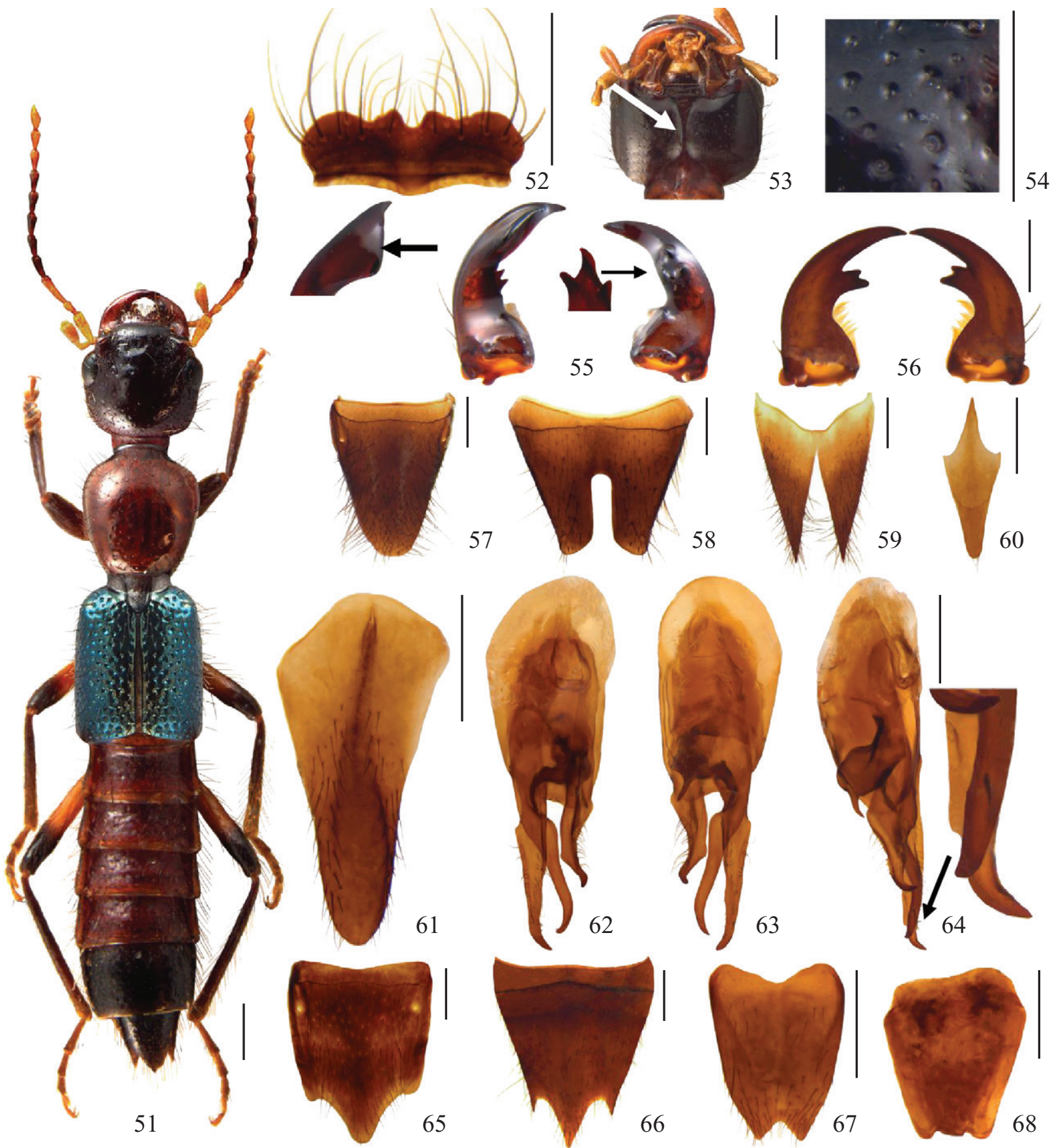

Figs. 51-68. Paederus ferus Figs. 51-55, 57-64, male; Figs. 56, 65-68 female; 51. Habitus, dorsal view; 52. Labrum, dorsal view; 53. Head, ventral view; 54. Vertex of head, dorsal view; 55. Mandibles, dorsal view, (larger arrow, lateral view), (smaller arrow, ventral view); 56. Mandibles, dorsal view; 57. Tergite 8 , dorsal view; 58 . Sternite 8 , ventral view; 59 . Tergite 9, dorsal view; 60 . Tergite 10 , dorsal view; 61 . Sternite 9 , ventral view; 62 . Aedeagus, ventral view; 63. Aedeagus, dorsal view; 64. Aedeagus, lateral view; 65. Tergite 8, dorsal view; 66. Sternite 8 , ventral view; 67. Sternite 9 , ventral view; 68. Genital plate; Scale bar $=1 \mathrm{~mm}$, Fig. 51; $0.5 \mathrm{~mm}$, Figs. 52-68.

\section{Paederus mutans Sharp, 1876}

(Figs. 69-84)

Paederus mutans Sharp 1876: 286 (original description, type locality “Tapajos and Pará”); Frank, 1988: 123 (catalog with details about previous citations).

Diagnosis. Paederus mutans is similar to P. amazonicus in body length, emarginated apex of sternite 9 th of male and truncate apex of sternite 9th of female. It differs for the red head and apex of median lobe of aedeagus strongly narrowed and curved dorsally.

Redescription. $\mathrm{BL} \approx 8.8 \mathrm{~mm} ; \mathrm{BW} \approx 1.4 \mathrm{~mm}$.

Male. Body somewhat flattened dorsoventrally. Head red; quadrate, $\mathrm{HL} \approx 1.3 \mathrm{~mm}, \mathrm{HW} \approx 1.3 \mathrm{~mm}$, vertex inconspicuously punctate (Fig. 73). Eyes slightly protruding laterally. Antennae brownish yellow, 4-9 darker; long, almost reach- 

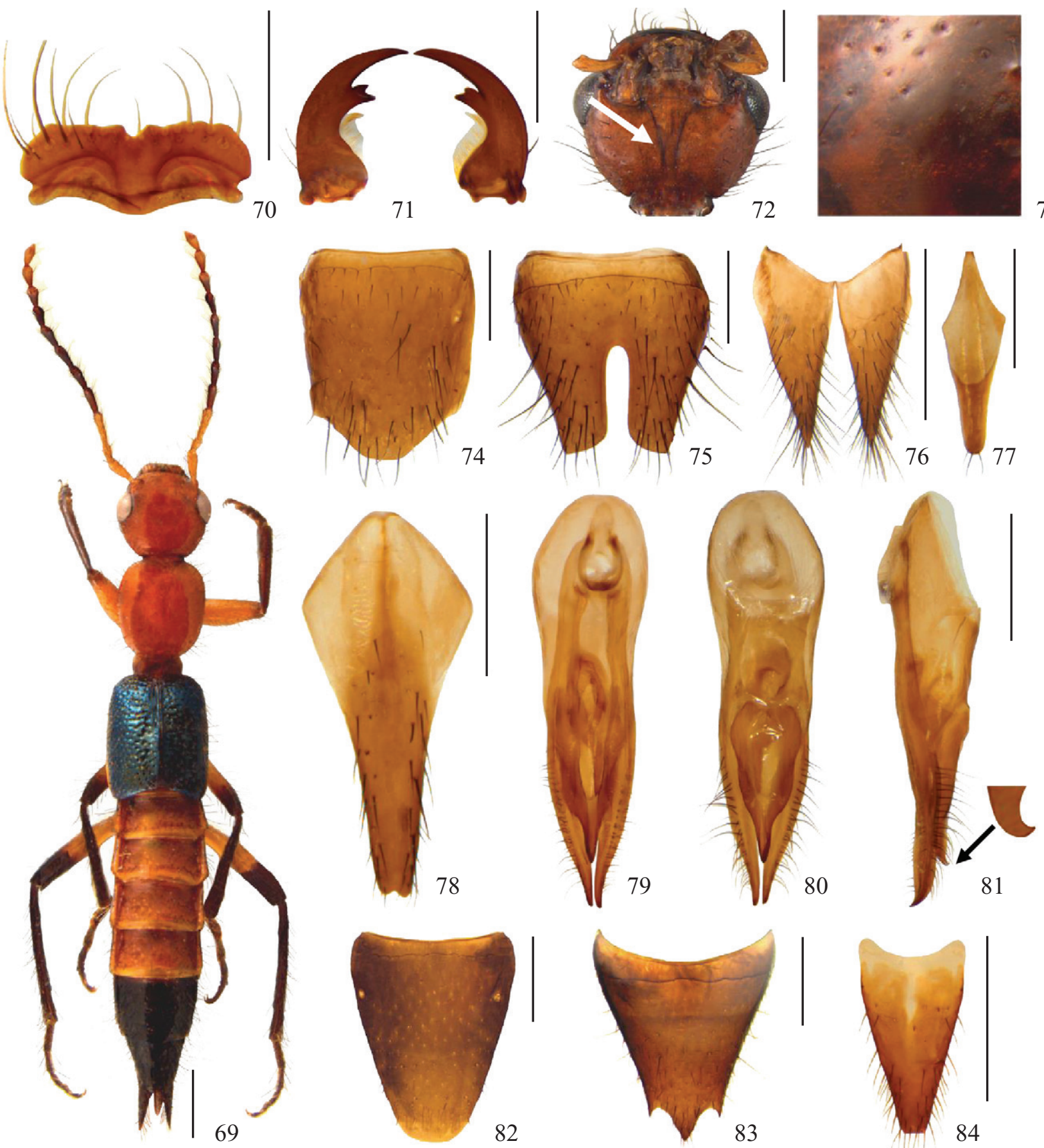

Figs. 69-84. Paederus mutans Figs. 69-81, male; Figs. 82-84 female; 69. Habitus, dorsal view; 70. Labrum, dorsal view; 71. Mandibles, dorsal view; 72. Head, ventral view; 73. Vertex of head, dorsal view; 74. Tergite 8th, dorsal view; 75. Sternite 8th, ventral view; 76. Paraproctos of the 9th tergite, dorsal view; 77. Sternite 9th, ventral view; 78. Sternite 9th, ventral view; 79. Aedeagus, ventral view; 80 . Aedeagus, dorsal view; 81 . Aedeagus, lateral view; 82. Tergite 8th, dorsal view; 83. Sternite 8th, ventral view; 84. Sternite 9th, ventral view. Scale bar $=1 \mathrm{~mm}$, Fig. $69 ; 0.5 \mathrm{~mm}$, Figs. $70-84$.

ing the apex of elytra. Labrum red, subtrapezoidal, apical margin slightly truncate and with long setae; rounded on the lateral margins (Fig. 70). Mandibles reddish brown, falciform and symmetrical; projection bifurcate at the median of internal border, anterior tooth shorter than the posterior (Fig. 71). Gular sutures approximate on the basal one-third (Fig. 72, arrow). Pronotum reddish, slightly narrowed than elytra, PL $\approx 1.5 \mathrm{~mm}, \mathrm{PW} \approx 1.4 \mathrm{~mm}$, somewhat oviform, widest on the apical two-thirds; disc very convex, longitudinal median area not punctate and glabrous, lateral areas with sparse setaceous punctures. Elytra blackish blue with metallic gloss; rectangular, $\mathrm{EL} \approx 1.9 \mathrm{~mm}$; parallel sides; humeral angles slightly rounded; apical margin truncate; punctate and more conspicuous than from head and pronotum; wings well developed. Legs 
long; covered with brownish yellow macrosetae; profemur entirely brownish yellow; meso- and metafemur with apical one-third dark brown; all tibiae entirely brownish yellow; protarsi wider than meso- and metatarsi and the four first segments bilobed. Abdomen with segments 3-6 with parallel sides; 3-6 reddish and 7-10 black; 8th tergite subrectangular, apical margin truncate to rounded (Fig. 74); 8th sternite subtrapezoidal, posterior margin strongly emarginated and its internal border with parallel sides, each lateral angle of apical margin oblique (Fig. 75); paraproct of 9th tergite contiguous at the basal region, apex strongly acute and long setae (Fig. 76); apex of 10th tergite rounded and with long setae (Fig. 77); 9th sternite elongate, apex slightly emarginate (Fig. 78). Aedeagus with median lobe almost reaching the apex of lateral lobes; median lobe with hooked apex oriented dorsally (Fig. 81, arrow); lateral lobes symmetrical, apices contiguous, apex slightly curved ventrally and with lateral bristles on apical half (Figs. 79-81).

Female. Similar to male except for the following characters: 8th tergite subtrapezoidal with apical margin truncate to rounded (Fig. 82); 8th sternite subtriangular, apical margin tridentate with median acute apex (Fig. 83); 9th sternite in a single plate, elongate, basal margin wider than apical, apicalmargin truncate (Fig. 84).

Distribution records of the material examined. Brazil: Amazonas (Manaus, Presidente Figueiredo, Nhamunda, Querari), Pará (Itaituba, Jacareacanga), Maranhão (Chapadinha) and Espírito Santo.

Medical Importance. There is no record of incidents in the database of Brazilian SUS. However, in 2010 there were incidents in the region of the municipality of Chapadinha, Maranhão State (personal communication, Mr. Francinaldo S. Silva - UFMA). So, this is the first record of an incident involving this species.

Type material. Syntype deposited in BMNH, one male, dissected, fixed on cardboard, sealed between two plates of glass slide. Manuscript on paper card with the following information: "Paederus"/"mutans"/"Type"/"D.S.". The first label is printed and contains the following information, "Type" [white label with red border]; the second is handwritten, "Tapajos" [green label]; the last two are printed and contains the following information, "S. America:/Brasil." [white label with midline green], "Sharp Coll/1905 - 313." [white label]. Note: Sharp (1876) mentions two males and two females. We examined only one male deposited in BMNH. According to Dr. Roger G. Booth there are 4 syntypes deposited in BMNH. Presumably all syntypes are in BMNH.

Additional material. BRASIL: Amazonas: $2 \mathrm{M}$, Manaus, CEPLAC Km 31, 8.V.1976, Erufino \& Nilce col. (INPA); 1 F, Presidente Figueiredo, Com. São Francisco Km 24, 26.VII- 3.VIII.2005, F. F. Xavier F. \& G. M. Lourido \& R. Machado col. (INPA); 1 M, Presidente Figueiredo, Est. de Balbina Km 12, 3-5. II. 2006, F. F. Xavier F. col. (INPA); 1 M, 1 F, Rio Nhamunda, lg. Areias, 17-20. V. 2008, Rafael \& equipe col. (INPA); 1 M, Querari, Pelotão, 8-9. IV. 1993, Motta C. \& Ferreira R. \& Vidal \& Matteo B. col. (INPA); 1 M, Lago do Janaoacá, 26. III. 1988, Amorim M. col. (INPA); Para: 2 F, Itaituba, 16.X.1977, B. C. Ratclife col. (INPA); 1 F,
Jacareacanga, 0.IV.1969, F. R. Barbosa col. (INPA); Maranhão: 2 M, F, Chapadinha, Mata de Galeria 8-10h, 5.VIII.2009, F. S. Silva col. (DZUP); Espírito Santo: 1 M, 2.IX.1948, no collector (MZSP).

\section{Paederus protensus Sharp, 1876 revalidated status}

(Figs. 85-100)

Paederus protensus Sharp 1876: 287 (original description, type locality: "Pará"); Fauvel 1891: 100 (the first time cited as junior synonym of $P$. columbinus Laporte, 1835); Frank, 1988: 123 (catalog with details about previous citations)

Diagnosis. Paederus protensus is similar to P. amazonicus and $P$. columbinus in size and apex of female 8 th sternite which have a rounded projection on the median portion of apical margin. It differs from these two species in the apex of the median lobe of aedeagus with a sharp spike-shaped projection oriented dorsally and female 9th sternite bilobed and asymmetrical.

Redescription. $\mathrm{BL} \approx 8.1 \mathrm{~mm} ; \mathrm{BW} \approx 1.4 \mathrm{~mm}$.

Male. Body somewhat flattened dorsoventrally. Head black; subhexagonal, $\mathrm{HL} \approx 1.0 \mathrm{~mm}$; HW $\approx 1.1 \mathrm{~mm}$, vertex punctate, distance between coarse punctures longer than the diameter of each puncture (Fig. 89); Eyes protruding. Antennae brownish yellow; long, almost reaching the apex of elytra. Labrum reddish brown, subrectangular, apical margin truncate, median twice small teeth and long setae on apical margin (Fig. 86). Mandibles reddish brown, falciform and symmetrical; projection bifurcate at the median of internal border, anterior tooth shorter than the posterior (Fig. 87). Gular sutures approximate the basal half (Fig. 88, arrow). Pronotum reddish, somewhat narrowed than elytra, $\mathrm{PL} \approx 1.2$ $\mathrm{mm}, \mathrm{PW} \approx 1.1 \mathrm{~mm}$; nearly oviform, slightly widest on the apical two-thirds; disc very convex, longitudinal median area not punctate and glabrous, lateral areas with sparse setaceous punctures. Elytra blackish blue with metallic gloss; rectangular, $\mathrm{EL} \approx 1.8 \mathrm{~mm}$; parallel sides; humeral angles slightly rounded; apical margin truncate; punctate and more conspicuous than from head and pronotum; wings well developed. Legs long, covered with brownish yellow macrosetae; profemur brownish yellow and darker on apical one-fourth; meso- and metafemur brownish yellow and darker on apical one-third; all tibiae entirely dark brown; protarsi wider than meso- and metatarsi and the four first segments bilobed. Abdomen with segments 3-6 of parallel sides; 3-6 reddish and 7-10 black; 8th tergite subtriangular, apical margin rounded (Fig. 90); 8th sternite subtrapezoidal, posterior margin strongly emarginate and its internal border with parallel sides, each lateral of apical margin oblique (Fig. 91); paraproct of 9 th tergite contiguous at the basal region, apex strongly acute and long setae (Fig. 92); apex of 10th tergite rounded and with long setae (Fig. 93); 9th sternite elongate, apex rounded (Fig. 94). Aedeagus with median lobe not reaching the apex of lateral lobes, apex of median lobe hooked shaped dorsally directed (Fig. 97, narrow); lateral lobes with apexes contiguous, symmetrical, narrow and slightly curved ventrally, with lateral bristles on apical half (Figs. 95-97). 


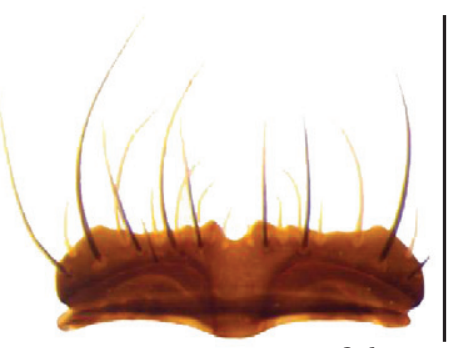

86

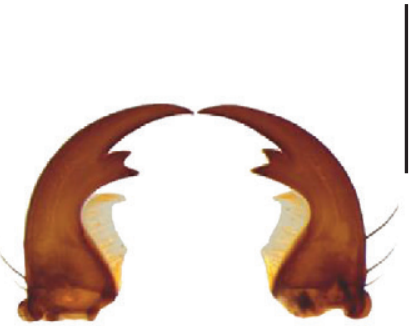

87

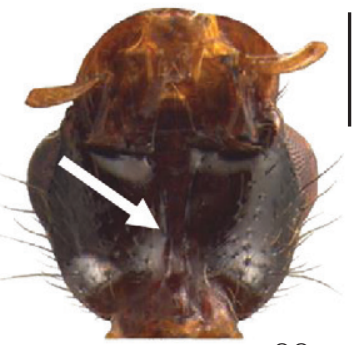

88

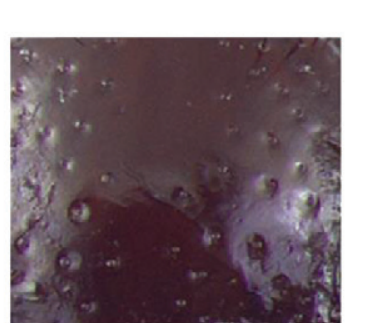

89

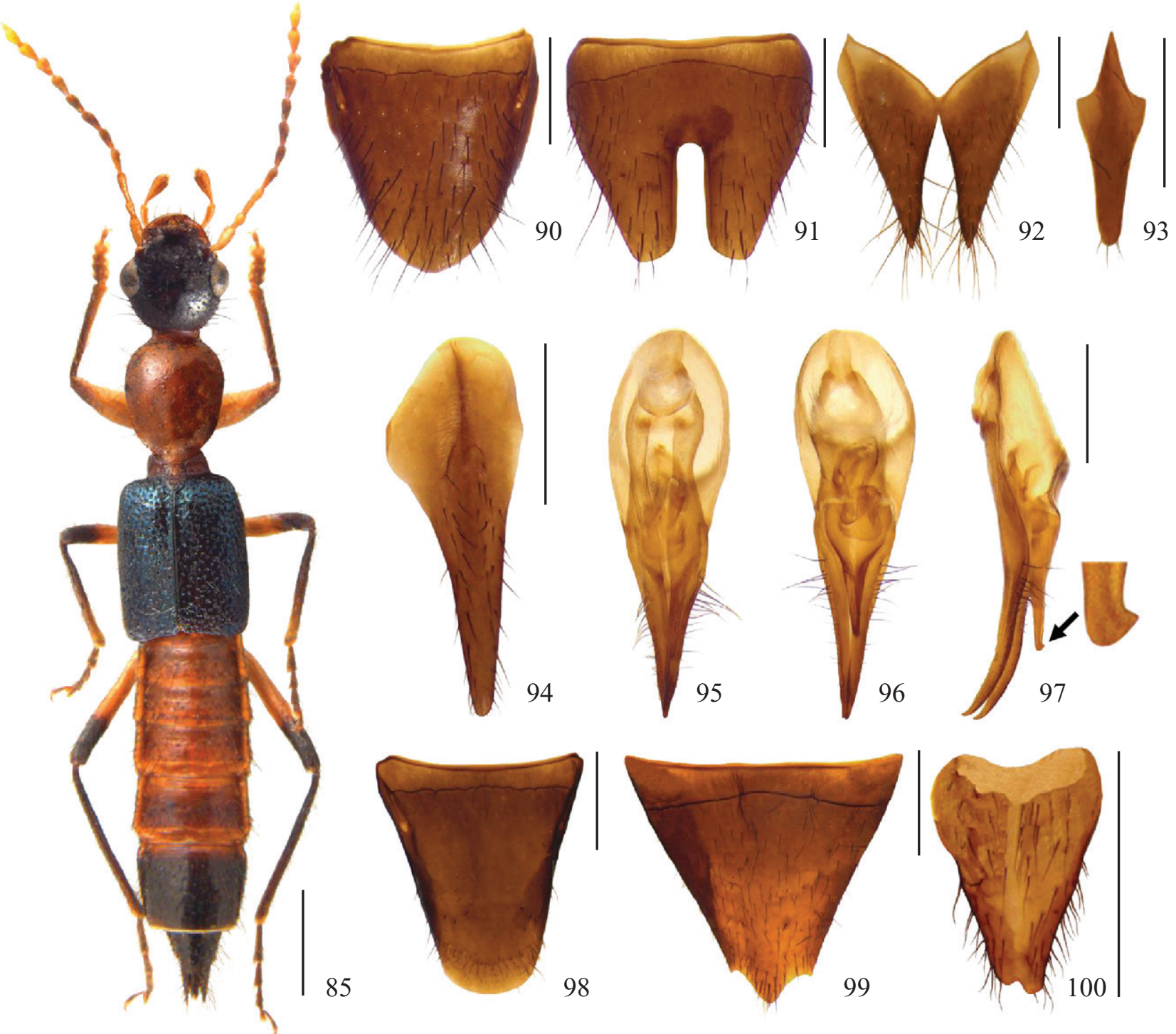

Figs. 85-100. Paederus protensus Figs. 85-97, male; Figs. 98-100 female; 85. Habitus, dorsal view; 86. Labrum, dorsal view; 87. Mandibles, dorsal view; 88. Head, ventral view; 89 . Vertex of head, dorsal view; 90 . Tergite 8 th, dorsal view; 91 . Sternite 8 th, ventral view; 92 . Tergite 9 th, dorsal view; 93. Tergite 10th, dorsal view; 94. Sternite 9th, ventral view; 95. Aedeagus, ventral view; 96. Aedeagus, dorsal view; 97 . Aedeagus, lateral view; 98. Tergite 8th, dorsal view; 99. Sternite 8th, ventral view; 100. Sternite 9th, ventral view. Scale bar $=1 \mathrm{~mm}$, Fig. $85 ; 0.5$ mm, Figs. $86-100$.

Female. Similar to male except for the following characters: 8th tergite subtrapezoidal with apical margin rounded (Fig. 98); 8th sternite subtriangular, apical margin with apex slightly acute (Fig. 99); sternite 9 elongate, basal margin wider than apical; apical margin bilobed and asymmetrical (Fig. 100); no genital plates.
Distribution records of the material examined. Brazil: Bahia (Lençóis, Rio de Contas), Maranhão (Chapadinha), Ceará (Sobral), Espírito Santo (Linhares), Minas Gerais (Betim).

Medical Importance. There is no record of incidents in the database of Brazilian SUS. However, Amado et al. (2010) 
report $P$. brasiliensis causing dermatitis in Betim, Minas Gerais State, but the material studied by Amado is the true $P$. protensus. In 2010 there were incidents in the municipality of Chapadinha, Maranhão State (Francinaldo S. Silva, pers. comm.). So, here we record this species for the first time as of medical importance, independently of its previous taxonomic situation.

Type material. Syntype deposited in BMNH, one male, dissected, fixed on cardboard sealed between two plates of glass slides, with a male symbol. Manuscript on paper card with the following information: "Paederus"/"protensus" amazons/"Type"/"D.S.". The first label is printed and has the following information, "Type" [white label with red border]; the second is handwritten, "Pará" [green label]; the last two are printed and have the following information, "S. America:/ Brasil.” [white label with midline green], "Sharp Coll/1905 - 313." [white label]. Note: Sharp (1876) studied four specimens and according to Dr. Roger G. Booth there are 3 syntypes deposited in BMNH, of which we observed only one male. The fourth syntype has not been found. Presumably all syntypes are deposited in BMNH. Since Fauvel (1891) this name is considered junior synonym of $P$. columbinus Laporte, 1835, but through the analyses of the type material from both names it was possible to separate in two morphological distinct species, so here we revalidate the species $P$. protensus Sharp, 1876.

Additional material. BRASIL: Bahia: 1 M, 1 F, Lençóis, Ribeirão de Baixo, 4.VI.2007, J. A. Rafael \& F. F. Xavier Fo. Luz col. (DZUP); 2 M, 5 F, Rio de Contas, 28.I, 3.II. 2005; 25-30.I.2007, Mielke \& Casagrande col. (DZUP); Maranhão: 14 M, 10 F, Chapadinha, 8,13,17,19,21,24. VIII.2009, 16, 25.I.2010, F. S. Silva col. (DZUP); Ceará: 1 M, Sobral, IV.1957, no collector (MZSP); Espírito Santo: 1 F, Linhares, 5-6.V.2007, J.A. Rafael, F.F. Xavier Fo. col. (INPA); Minas Gerais: 1 M, 1 F, Betim, 2009, no collector, (DZUP); 2 F, 2 M, Betim, 2009, R.C. Amado col. (DZUP).

\section{Paederus rutilicornis Erichson, 1840}

(Figs. 101-118)

Paederus rutilicornis Erichson, 1840: 666 (original description, type locality: "Bogotae in Columbia interiore"); Frank \& Kanamitsu, 1987: 158 (main reference indicating medical importance); Frank, 1988: 130 (catalog with details about previous citations).

Paederus lugubris Motschulsky, 1858: 635 (original description, type locality: "Brésil"); Gemminger \& Harold 1868: 628 (first time cited as junior synonym of P. rutilicornis Erichson, 1840); Frank, 1988: 119 (catalog with details about previous citations).

Diagnosis. Paederus rutilicornis is similar to P. ferus and P. brasiliensis due to the presence of the female genital plate. However, it differs from these two species for its entirely dark color, asymmetrical mandibles in both sexes, absence of posterior wings and lateral lobes of aedeagus asymmetrical in male.

Redescription. $\mathrm{BL} \approx 14.5 \mathrm{~mm} ; \mathrm{BW} \approx 2.0 \mathrm{~mm}$.

Male. Body somewhat flattened dorsoventrally. Head black, subrectangular, $\mathrm{HL} \approx 2.7 \mathrm{~mm}, \mathrm{HW} \approx 2.4 \mathrm{~mm}$; vertex punctate, distance between coarse punctures longer than the diameter of each puncture (Fig. 105). Eyes protruding. Antennae brownish yellow; long, almost reaching the apex of elytra. Labrum dark brown, subrectangular, apical margin truncate with conspicuous median emargination, oblique lateral margins (Fig. 102). Mandibles brown, falciform and asymmetrical, right mandible with one tooth in the median of internal border; left mandible with a projection bifurcated at the median of internal border, anterior tooth shorter than the posterior (Fig. 103). Gular sutures strongly approximates at the basal half (Fig. 104, arrow). Pronotum black, almost the same wide of elytra, $\mathrm{PL} \approx$ $2.8 \mathrm{~mm}, \mathrm{PW} \approx 2.4 \mathrm{~mm}$, nearly oviform, slightly widest on the apical two-thirds; disc very convex, longitudinal median area not punctate and glabrous, lateral areas with sparse setaceous punctures. Elytra blackish blue with metallic shine; rectangular, $\mathrm{EL} \approx 3.1 \mathrm{~mm}$, with sides slightly parallel, humeral angles rounded; apical margin oblique; punctate and more conspicuous than from head and pronotum; wings not developed. Legs long; covered with brownish yellow macrosetae; femurs and tibiae entirely black; protarsi wider than meso- and metatarsi and the four first segments bilobed. Abdomen elongate; entirely black, ventrite 3-6 with parallel sides; 8 th tergite subquadrate, apical margin rounded (Fig. 106); 8th sternite subtrapezoidal, posterior margin strongly emarginate and its internal border with parallel sides, each lateral of apical margin oblique (Fig. 107); paraproct of 9th tergite contiguous at the basal region, apex strongly acute and long setae (Fig. 108); apex of 10th tergite rounded and with long setae(Fig. 109); 9th sternite elongate, apex somewhat emarginated to truncate (Fig. 110). Aedeagus with median lobe with abrupt apex and assymetrical, almost reaching the apex of right lateral lobe in dorsal view (Fig. 112); lateral lobes asymmetrical, inner margin of parallel sides, apex curved ventrally, right lateral lobe with four small spines (Fig. 113, arrow).

Female. Similar to male except for the following characters: 8th tergite subtrapezoidal, with apical margin rounded (Fig. 114); 8th sternite subtriangular, apical margin with median projection of acute apex (Fig. 115); 9th sternite in single plate, subtriangular, basal margin wider than apical, apical margin truncate (Fig. 116); dorsal genital plate subquadrate and rounded (Fig. 117), ventral rectangular and strongly curved (Fig. 118).

Distribution records of the material examined. Colombia (Bogotá, Pacho, Cudinamarca).

Medical Importance. There is no record of incidents in the database of Brazilian SUS. However, Froes (1935) reports this species in Bahia state. During this study, all material of $P$. rutilicornis observed was from Colombia. The study of the type of P. lugubris possibly will clarify the taxonomic situation of the two names.

Type material. Paederus rutilicornis: syntypes deposited in $\mathrm{ZMHB}$, two female and three males. One syntype with the following information: "Bogotá Buq. [green label]”, "6467 [white label]", "rutilicornis/(two illegible letters) [green label], "Type" [orange label]., "SYNTYPUS/Paederus/rutilicornis Erichson, 1840/labelled by MNHUB 2012" [red label]. The others with the following information: "Bogotá" [white label, handwritten],'Hist.-Coll. (Coleoptera)/Nr. 6467/Paederus/ 


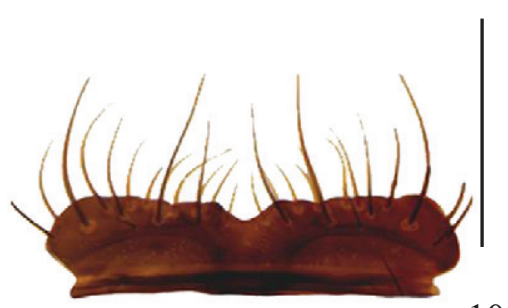

102

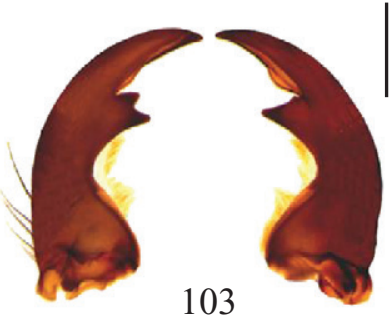

103
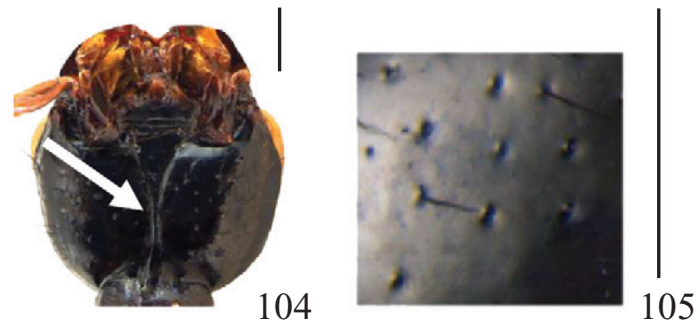
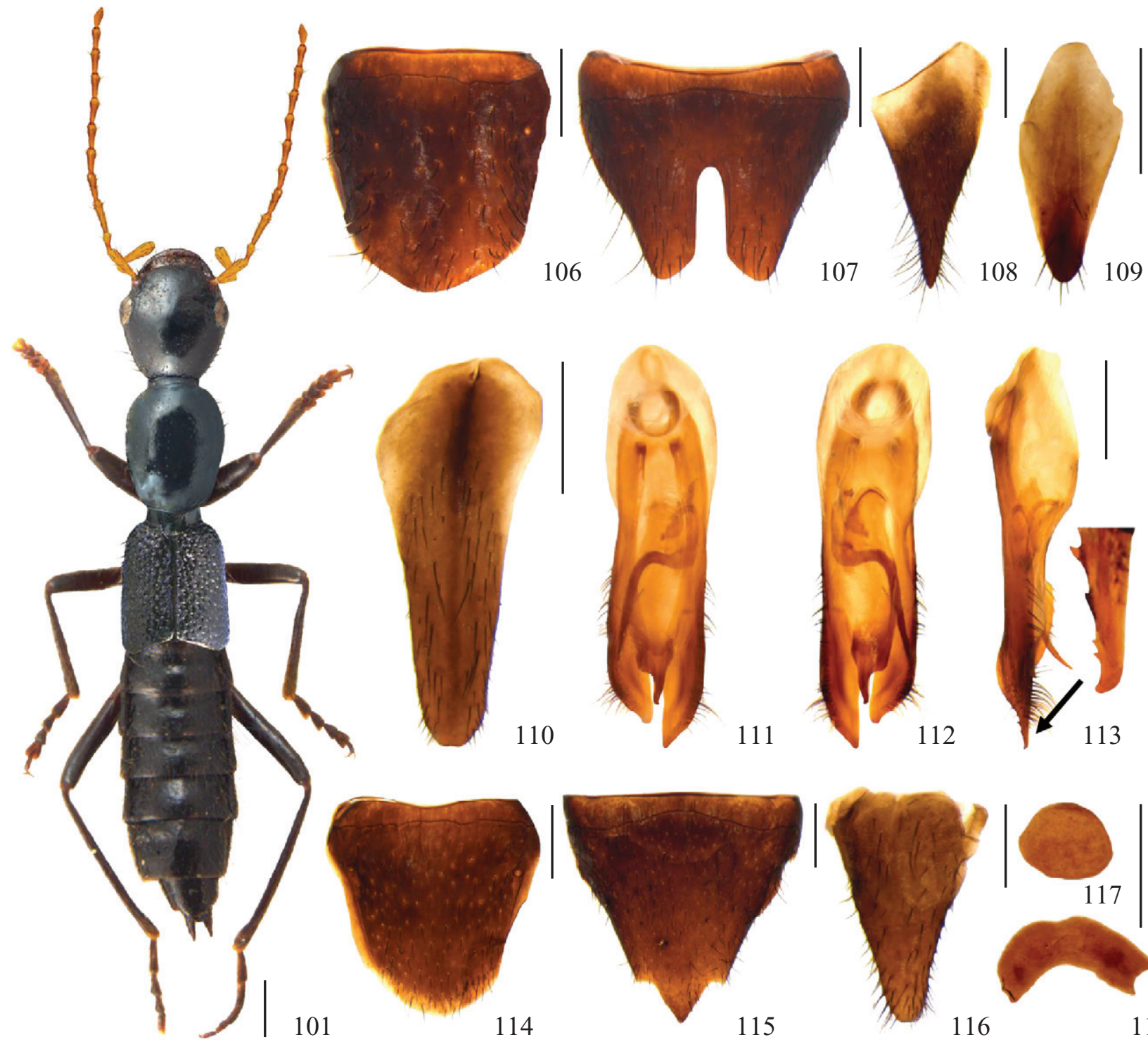

109
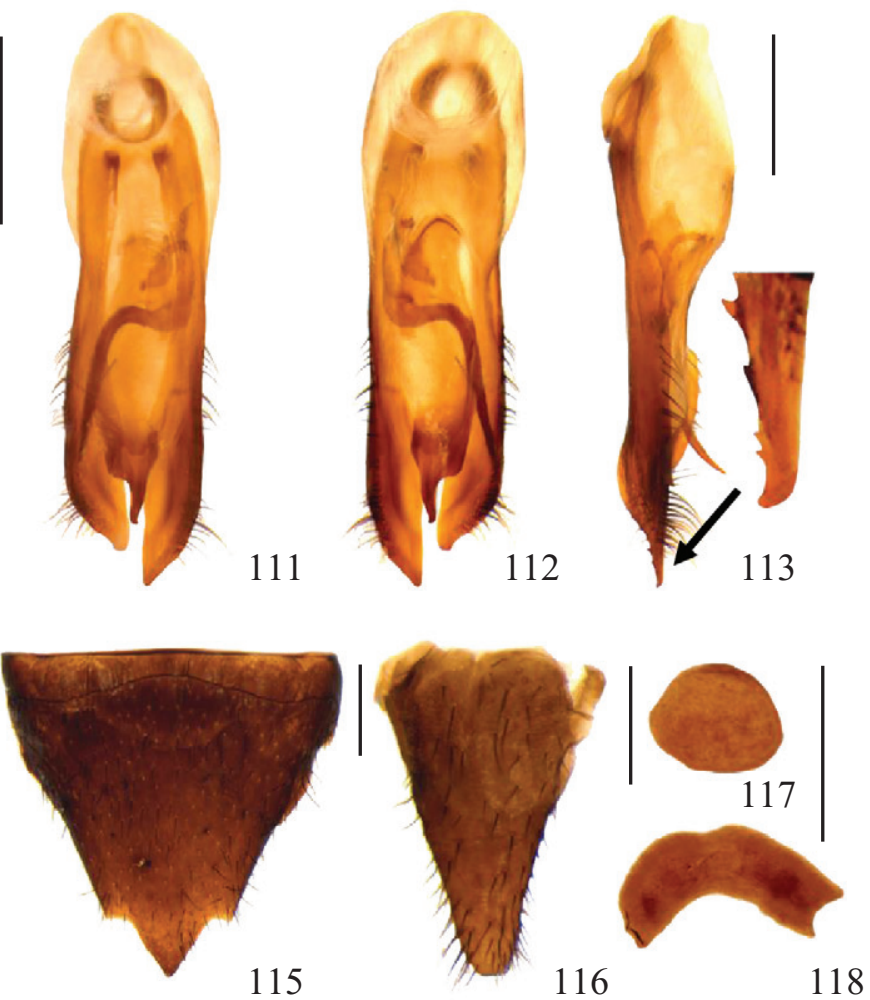

Figs. 101-118. Paederus rutilicornis Figs. 101-113, male; Figs. 114-118 female; 101. Habitus, dorsal view; 102. Labrum, dorsal view; 103. Mandibles, dorsal view; 104. Head, ventral view; 105. Vertex of head, dorsal view; 106. Tergite 8th, dorsal view; 107. Sternite 8th, ventral view; 108 . Tergite 9th, right part, dorsal view; 109. Tergite 10th, dorsal view; 110. Sternite 9th, ventral view; 111. Aedeagus, ventral view; 112 . Aedeagus, dorsal view; 113. Aedeagus, lateral view; 114. Tergite 8th, dorsal view; 115. Sternite 8th, ventral view; 116. Sternite 9th, ventral view; 117 . Genital plate, part; 118. Genital plate, part. Scale bar $=1 \mathrm{~mm}$, Fig. 101; $0.5 \mathrm{~mm}$, Figs. 102-118.

rutilicornis Erichs./Bogotá., Buq./Zool. Mus. Berlin” [green label], "SYNTYPUS/Paederus/rutilicornis Erichson, 1840/labelled by MNHUB 2012" [red label]. Note: Erichson (1840) did not specify how many specimens he observed. We received from ZMHB three males and two females labeled as type. Presumably all syntypes are deposited in ZMHB. Paederus lugubris: syntype deposited at the Zoological Museum of Moscow University (ZMUM), a female, not observed.

Additional material. COLOMBIA: $1 \mathrm{M}$, no locality, no date, no collector (FMNH); $1 \mathrm{M}$, Bogotá, don. Shandinga, no date, no collector (FMNH); Cundinamarca: 5 F, 3 M, Pacho, no date, 1900atm, Corwill col. (FMNH); 20 F, 14 M, Pacho, no date, 2000atm, Corwill col. (FMNH). 


\section{CONCLUSION}

We summarize here the main results of this complete taxonomic revision of the species of Paederus of medical importance in Brazil. Seven species of Paederus have been recorded in Brazil causing dermatitis, of which five, $P$. brasiliensis, $P$. columbinus, P.ferus, P. mutans and P. protensus, are confirmed with study of voucher material. On the other hand, $P$. amazonicus and P. rutilicornis are cited as having medical importance based only on old literature, in which misidentification is possible. Moreover, two species are listed for the first time as of medical importance, $P$. mutans and P. protensus, the latest previously considered as a junior synonym of $P$. columbinus and here revalidated.

Before the current study, species of Paederus of medical importance in Brazil had been recorded in 11 States, all based on diverse literature: Amazonas, Pará, Ceára, Paraíba, Pernambuco, Alagoas, Sergipe, Goiás, Minas Gerais, São Paulo and Paraná. Now, we recorded six additional States: Maranhão, Rio Grande do Norte, Mato Grosso, Espírito Santo, Rio de Janeiro and Santa Catarina.

However, during this study no material of Paederus of medical importance has been seen in Paraíba, Pernambuco and Alagoas. At the moment, there is no record of any species of Paederus of medical importance in the following 10 Brazilian States: Roraima, Amapá, Acre, Rondônia, Tocantins, Piauí, Sergipe, Distrito Federal, Mato Grosso do Sul and Rio Grande do Sul. It is a general consensus, however, that these states cannot be considered free of Paederus of medical importance. Regarding the presence of the species in the main five regions of Brazil, the confirmed geographic distribution of each species of Paederus of medical importance shows that $P$. amazonicus occurs in the north and central-west regions, $P$. brasiliensis in almost all of the five regions, except the central-west one, $P$. columbinus in north and northeast regions, $P$. ferus in southeast and south regions, P. mutans in north, northeast and southeast regions and $P$. protensus in northeast, central-west and southeast regions. In contrast, $P$. rutilicornis was confirmed only for Colombia and its record in Brazil needs to be confirmed, possibly after the study of the type of P. lugubris.

Five species are also here confirmed in other countries, $P$. amazonicus in Peru, P. brasiliensis in Argentina, P. columbinus in Panama and Venezuela, P. ferus in Ecuador and Bolivia, and $P$. rutilicornis found only in Colombia.

\section{ACKNOWLEDGMENTS}

We thank Gisélia B. G. Rubio (SESA/PR), Emanuel M. Silva (SESA/PR), Roberto C. (SESA/MG), Francinaldo S. Silva (UFMA), Paschoal C. Grossi (UFPR) and to curators listed under "Material and methods" for the material which enabled this study. We thank the TAXonline-Rede Paranaense de Colecões Biológicas (UFPR) for the photos and Conselho Nacional de Desenvolvimento Cientifico eTecnológico (CNPq) for the scholarships to the first two authors. Finally, we are grateful to Alfred Newton (FMNH) and editors and anony- mous referees of Revista Brasileira de Entomologia for valuable suggestions on the manuscript.

\section{REFERENCES}

Albuquerque, H.N., Leite, C.F., Albuquerque, I.C.S \& M.L.F. Cavalcanti. 2008. Contribuição ao estudo dos potós (Paederus) em dois bairros da cidade de Campina Grande-PB. BioFar - Revista de Biologia e Farmácia 3: 26-37.

Amado, R.C., Rabelo, J.V.C., Braga, P.M.F. \& Chumbinho, S.A. 2010. Identificação de surto de dermatite causada por besouro potó (Paederus brasiliensis) em Betim, Minas Gerais, 2009. Epidemiologia e Serviços de Saúde 19: 403-405.

Bernhauer, M. 1915. Zur Staphyliniden-Fauna von Südamerika (13. Beitrag.) Stettiner Entomologische Zeitung 76: 291-301.

Bernhauer, M. 1931.Neuheiten der paläarktischen Staphylinidenfauna. Koleopterologische Rundschau 17: 232-245

Beutel, R.G. \& Leschen, R.A.B. (Editors). 2005. Handbook of Zoology, Volume IV Arthropoda: Insecta, Part 38, Evolution and Systematics Coleoptera (Archostemata, Adephaga, Myxophaga, Polyphaga part.). Berlin, Waltyer de Gruyter, 567 p.

Blackwelder, R.E. 1939. A generic revision of the staphylinid beetles of the tribe Paederini. Proceedings of the United States National Museum 87: 93-125.

Blackwelder, R.E. 1944. Checklist of the coleopterous insects of Mexico, Central America, the West Indies, and South America. United States National Museum Bulletin 185: 1-188.

Blackwelder, R.E. 1952. The generic names of the beetle family Staphylinidae with an essay on genotypy. United States National Museum Bulletin 200: 1-483.

Cardoso, J.L.C. \& Haddad Jr., V. 2009. Acidentes por Coleópteros Vesicantes, p. 258-264. In: Cardoso J.L.C., França F.O.S., Wen F.H., Málaque C.M.S \& Haddad Jr., V. (Orgs). Animais peçonhentos no Brasil: biologia, clínica e terapêutica dos acidentes. São Paulo, Sarvier, v+468 p.

Casey, T.L. 1905. A revision of the American Paederini. Transactions of the Academy of Science of St. Louis 15: 17-248.

Chapin, E.A. 1926. A new Paederus (Coleoptera: Staphylinidae) causing vesicular dermatitis in man. Archiv für Schiffs und Tropenhygiene 30: $369-372$.

Chapin, E.A. 1927. A new genus and species of Staphylinidae from Sze-Chuan, China. Proceedings of the Biological Society of Washington 40: 75-77.

Curtis, J. 1826. British entomology; being illustrations and descriptions of the genera of insects found in Great Britain and Ireland: containing coloured figures from nature of the most rare and beautiful species, and in many instances of the plants upon which they are found. Vol. 3, London, J. Curtis, 9-146.

Czwalina, G. 1888 Die Forcipes der Staphyliniden Gattung Lathrobium (s. str. Rey) Grav. Deutsche Entomologische Zeitschrift 32: 337 354, more two plates.

Diógenes, M.J.N. 1994. Dermatite de contato pela pederina: estudo clínico e epidemiológico no estado do Ceará, Brasil. Revista do Instituto de Medicina Tropical 36: 59-65.

Erichson, W.F. 1840. Genera et species staphylinorum insectorum Coleopterorum familiae. Berlin, F.H. Morin, 401-954.

Fabricius, J.C. 1775. Systema entomologiae, sistens insectorum classes, ordines, genera, species, adiectis synonymis, locis, descriptionibus, observationibus. Flensburg and Leipzig, Kortius, 832 p.

Fagel, G. 1958. Paederini (Coleoptera Polyphaga) Fam. Staphylinidae. Exploration du Parc National de l'Upemba, Mission G. F. de Witte. 51: $1-470$.

Fain, A. 1966. Toxic action of rove beetles (Coleoptera: Staphylinidae) Memorias do Instituto Butantan 33: 835-844.

Fauvel, A. 1891. Voyage de M.E.Simon au Vénézuela (Décembre $1887-$ Avril 1888). 11e Mémoire. Revue d'Entomologie 10: 87-127.

Fonseca, J.M.V., Oliveira, C.M.N., Peluzio, R.J.E., Zanúncio, J.C. \& Fiorezi, J.M.S. 2012. Dermatite vesicante pelo Paederus sp.: relato de 19 ca- 
sos em Viçosa, Minas Gerais, Brasil. Revista Brasileira de Medicina Família e Comunidade 7: 25-30.

Frank, J.H. 1988. Paederus, sensu lato (Coleoptera: Staphylinidae): An index and review of the taxa. Insecta Mundi 2: 97-159.

Frank, J.H. \& Kanamitsu, K. 1987. Paederus, sensu lato (Coleoptera: Staphylinidae): natural history and medical importance. Journal of Medical Entomology 24: 155-191.

Froes, H.P. 1935. Observation on Brazilian "Blister Beetles". The Journal of Parasitology 21: 124.

Gautier des Cottes, C. 1861. Genre nouveau de staphylinien et description de nouvelles espèces de coléoptères de Syrie et d'Europe. Annales de la Société Entomologique de France 1: 75-78 (Published on August 14th, 1861).

Gautier des Cottes, C. 1862. Publications de la Société. Annales de la Société Entomologique de France 3: xxxvi (Published on January 22th, 1862).

Gemminger, M. \& Harold, E. von 1868. Catalogus Coleopterorum hucusque descriptorum synonymicus et systematicus. Vol. 2, Munich, 425-752.

Gistel, J. 1848. Naturgeschichte des Thierreichs für höhere Schulen. Stuttgart, Hoffman, xvi+216 p.

Gravenhorst, J.L.C. 1802. Coleoptera Microptera Brunsvicensia nec non exoticorum quotquot exstant in collectionibus entomologorum Brunsvicensium in genera familias et species distribuit. Brunswick, Reichard, 1xvi+206 p.

Gravenhorst, J.L.C. 1806. Monographia Coleopterorum Micropterorum. Göttingen. Typis Henrici Dietrich, 248 p.

Gusarov V.I. 2002. A revision of Nearctic species of the genus Geostiba Thomson, 1858 (Coleoptera: Staphylinidae: Aleocharinae). Zootaxa 81: 1-88.

ICZN.1999. International Code of Zoological Nomenclature, fourth edition. The International Trust for Zoological Nomenclature $1999 \mathrm{c} / \mathrm{o}$ The Natural History Museum, Cromwell Road, London, UK (last updated 01 January 2000). Available at://www.iczn.org/iczn/index.jsp (accessed in 26 January 2012).

Laporte, F.L. 1835. Études entomologiques, ou description d'insectes nouveaux, et observations sur la synonymie. Paris, Méquignon-Marvis, $159 \mathrm{p}$.

Latreille, P.A. 1810. Considérations générales sur l'ordre naturel des animaux composant les classes des crustacés, des arachnides et des insectes; avec un tableau méthodique de leurs genres, disposés en familles. Paris, F. Schoell, $444 \mathrm{p}$.

LeConte, J.L. 1858. Description of new species of Coleoptera, chiefly collected by the United States and Mexican Boundary Commission, under Major W.H. Emory, U.S.A. Proceedings of the Academy of Natural Sciences of Philadelphia 10: 58-89.

Li, X.-Y. \& Zhou, H.-Z. 2007. Study on the subgenus Harpopaederus of the genus Paederus Fabricius (Coleoptera, Staphylinidae, Paederinae) from China. Deutsche Entomologische Zeitschrift 54: 219-233.

Li, X.-Y. \& Zhou, H.-Z. 2009. A review of Chinese species of the subgenus Paederus s. str. (Coleoptera: Staphylinidae: Paederinae) with description of a new species. Zootaxa 2083: 46-64.

Linnaeus, C. v. 1758. Systema naturae per regna tria naturae: secundum classes, ordines, genera, species, cum characteribus, differentiis, synonymis, locis. Vol. 1. Ed. 10. Holmiae, Laurentii Salvii 824 p.

Mammino, J.J. 2011. Paederus dermatitis: An outbreak on a medical mission boat in the Amazon. Journal of Clinical and Aesthetical Dermatology 4: 4446.

Mannerheim, C.G. von 1830. Précis d'un nouvel arrangement de la famille des brachélytres, de l'ordre des insectes coléoptères. Mémoires de l'Académie Impériale des Sciences de St. Pétersbourg 1: 1-87.

Motschulsky, T.V. von. 1858. Enumération des nouvelles espèces de coléoptères rapportés de ses voyages. Bulletin de la Société Impériale des Naturalistes de Moscou 31: 634-670.

Naomi, S.-I. 1987a. Comparative morphology of the Staphylinidae and the allied groups (Coleoptera, Staphylinoidea). I. Introduction, head sutures, eyes, and ocelli. Kontyû 55: 450-458.

Naomi, S.-I. 1987b. Comparative morphology of the Staphylinidae and the allied groups (Coleoptera, Staphylinoidea). II. Cranial structure and tentorium. Kontyû 55: 666-675.

Naomi, S.-I. 1988a. Comparative morphology of the Staphylinidae and the allied groups (Coleoptera, Staphylinoidea). III. Antennae, labrum and mandibles. Kontyû 56: 67-77.
Naomi, S.-I. 1988b. Comparative morphology of the Staphylinidae and the allied groups (Coleoptera, Staphylinoidea). IV. Maxillae and labium. Kontyû 56: 241-250.

Naomi, S.-I. 1988c. Comparative morphology of the Staphylinidae and the allied groups (Coleoptera, Staphylinoidea). V. Cervix and prothorax. Kontyû 56: 506-513.

Naomi, S.-I. 1988d. Comparative morphology of the Staphylinidae and the allied groups (Coleoptera, Staphylinoidea). VI. Mesothorax and metathorax. Kontyû 56: 727-738.

Naomi, S.-I. 1989a. Comparative morphology of the Staphylinidae and the allied groups (Coleoptera, Staphylinoidea). VII. Metendosternite and wings. Japanese Journal of Entomology 57: 82-90.

Naomi, S.-I. 1989b. Comparative morphology of the Staphylinidae and the allied groups (Coleoptera, Staphylinoidea). VIII. Thoracic legs. Japanese Journal of Entomology 57: 269-277.

Naomi, S.-I. 1889c. Comparative morphology of the Staphylinidae and the allied groups (Coleoptera, Staphylinoidea). IX. General structure, lateral plates, stigmata and 1st to 7 th segments of abdomen. Japanese Journal of Entomology 57: 517-526.

Naomi, S.-I. 1989d. Comparative morphology of the Staphylinidae and the allied groups (Coleoptera, Staphylinoidea). X. Eigth to 10th segments of abdomen. Japanese Journal of Entomology 57: 720-733.

Naomi, S.-I. 1990. Comparative morphology of the Staphylinidae and the allied groups (Coleoptera, Staphylinoidea). XI. Abdominal glands, male genitalia and female spermatheca. Japanese Journal of Entomology 58: 16-23.

Navarrete-Heredia, J.L., V.H.G. Flores. 2005. Aspectos etnoentomológicos acerca de Paederus sp. (Coleoptera: Staphylinidae) en Mascota, Jalisco, México. Dugesiana 12: 9-18.

Perroud, B.-P. \& Montrousier, P. 1864. Essai sur la faune entomologique de Kanala (Nouvelle-Calédonie) et descriptions de quelques espèces nouvelles ou peu connues. Annales de la Société Linnéenne de Lyon 11: 46-257.

Pickel, B. 1940a. Uma dermatite purulenta causada por potós em São Paulo. Arquivos Biológicos de São Paulo 24: 153-156.

Pickel, B. 1940b. Dermatite purulenta produzida por duas espécies de Paederus. Revista de Entomologia 11: 775-793.

Scheerpeltz, O. 1957. Vorläufige Diagnosen einiger neuen palaarktischen Arten und Formen der Gattungen Paederidus Muls. Rey, Paederus Fabr. (mit den neuen Untergattungen Eupaederus, Paederus s. str. nov., Heteropaederus, Dioncopaederus und Oedopaederus), Parameropaederus nov. gen., Lobopaederus nov. gen. und Megalopaederus nov. gen. Memorie del Museo di Storia Naturale della Venezia Tridentina 11: 447-475.

Scheerpeltz, O. 1966. Ergebnisse der Österreichischen NeukaledonienExpedition 1965. Staphylinidae. Annalen des Naturhistorischen Museums in Wien 69: 393-418.

Scheerpeltz, O. 1976. Wissenschaftliche Ergebnisse entomologischer Aufsammlungen in Nepal (Col. Staphylinidae). Khumbu Himal 5: 77-173.

Sharp, D. 1876. Contributions to an insect fauna of the Amazon Valley: Coleoptera- Staphylinidae. Transactions of the Entomological Society of London 1876: 27-424.

Silva, P. 1912. Le Paederus columbinus est vésicant? Archives de Parasitologie 15: 429-431.

Torres, O. 1922. Contribuição ao estudo de algumas lesões determinadas pelos arthrópodos (arachnideos, myriapodos e insectos). Anales del Primero Congreso de Dermatología y Sifilografía 141-153.

Wendeler, H. 1927. Ein neues Subgenus und eine neue Species des Genus Paederus (Col, Staphyl.) 15. Beitrag zur Kenntnis der Staphyliniden. Neue Beiträge zur Systematischen Insektenkunde 4: 1-2.

Wendeler, H. 1928. Paederognathus nom. nov. (Col. Staphylin.). Deutsche Entomologische Zeitschrift 1928: 37.

Wendeler, H. 1931.Eine Reihe neuer Paederus-Arten aus verschiedenen exotischen Faunengebieten (Col. Staph.). (12. Beitrag zur Kenntnis der Staphyliniden). Neue exotische Staphyliniden (Coleoptera). Deutsche Entomologische Zeitschrift 1931: 37-48.

Received 27 November 2013; accepted 13 May 2014

Associate Editor: Marcela L. Monné 